\title{
Stratigraphy and palaeoenvironment of Stajnia Cave (southern Poland) with regard to habitation of the site by Neanderthals
}

\author{
Marcin ŻARSKII , *, Hanna WINTER ${ }^{1}$, Adam NADACHOWSKI ${ }^{2}$, Mikołaj URBANOWSKI ${ }^{3}$, Paweł SOCHA ${ }^{4}$, \\ Krystyna KENIG ${ }^{1}$, Bogusław MARCINKOWSKI ${ }^{1}$, Ewa KRZEMIŃSKA ${ }^{1}$, Krzysztof STEFANIAK $^{4}$, \\ Wioletta NOWACZEWSKA ${ }^{5}$ and Adrian MARCISZAK ${ }^{4}$
}

\author{
1 Polish Geological Institute - National Research Institute, Rakowiecka 4, 00-975 Warszawa, Poland \\ 2 Institute of Systematics and Evolution of Animals, Polish Academy of Sciences, \\ Sławkowska 17, 30-611 Kraków, Poland \\ 3 Szczecin University, Institute of History and International Relations, Department of Archaeology, \\ Krakowska 71-79, 71-017 Szczecin, Poland \\ 4 Department of Paleozoology, Institute of Environmental Biology, University of Wrocław, Sienkiewicza 21, \\ 50-335 Wrocław, Poland \\ 5 Department of Human Biology, University of Wrocław, Kuźnicza 35, 50-138 Wrocław, Poland
}

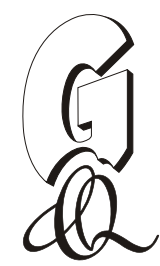

\begin{abstract}
Żarski, M., Winter, H., Nadachowski, A., Urbanowski, M., Socha, P., Kenig, K., Marcinkowski, B., Krzemińska, E., Stefaniak K., Nowaczewska, W., Marciszak, A., 2017. Stratigraphy and palaeoenvironment of Stajna Cave (southern Poland) with regard to habitation of the site by Neanderthals. Geological Quarterly, 61 (2): 350-369, doi: 10.7306/gq.1355

The Stajnia Cave is one of the most important archaeological sites due to the finds of the first remains of Neanderthals in Poland, and several tens of thousands of flint artefacts from the Middle Palaeolithic. Based on geological, geochemical, palaeobotanical, palaeozoological, archaeological and isotope analyses, coupled with absolute age determinations (OSL, $\mathrm{U}-\mathrm{Th}$ and $\mathrm{C}^{14}$ ), 15 lithostratigraphic layers were distinguished and palaeoenvironmental conditions during the sedimentation of these beds were determined. The cave loams accumulated through weathering, aeolian and fluvial processes. Their age may be correlated with an interval from the Early Glacial to the Late Pleniglacial of the Visulian (Weichselian) Glaciation. Archaeological relics related to the Neanderthals have been discovered in layer $D$ with an absolute age of about 52,000-45,000 years BP and correlated with MIS 3 - the Middle Plenivistulian (Interplenivistulian). Climate oscillations in the Vistulian are reflected by the type of the sediments and their physical-chemical features, allowing determining warmer interstadial and colder stadial periods. Generally, the climate was cold, characteristic of tundra areas with a typical vegetation and fauna, and with the mean temperature of the warmest month not exceeding $12^{\circ} \mathrm{C}$. Based on multi-proxy studies it can be concluded that from layer E1 upwards, the climate conditions became progressively drier. At that time, the climate was cold with continental features enhancing tundra domination. This conclusion is confirmed by palaeontological investigations and the record of stable oxygen isotopes in the teeth of reindeer. The studies have also indicated seasonal migration of reindeer on the tundra that surrounded the cave. Probably, short-term slight climate warmings occurred during the Middle Plenivistulian (Interplenivistulian).
\end{abstract}

Key words: Stajnia Cave, Neanderthal, Vistulian, palaeoenvironment, Częstochowa Upland.

\section{INTRODUCTION}

Most archaeological cave sites in Poland are situated in the Polish Jura Chain known in the literature under the name Kraków-Częstochowa Upland (Fig. 1). Over 50 caves and rock shelters have been excavated in the region during the last 140 years (Madeyska and Cyrek, 2002). Archaeological, geological and palaeontological investigations have been conducted in the

\footnotetext{
* Corresponding author, e-mail: marcin.zarski@pgi.gov.pl

Received: June 1, 2016; accepted: February 6, 2017; first published online: March 29, 2017
}

Polish caves since the end of the 19th century, mainly in the vicinity of Ojców near Kraków (Zawisza, 1874; Römer, 1883; Ossowski, 1885). One of the most important archaeological sites of the Middle Palaeolithic, being still excavated, is the Ciemna Cave in the Prąnik Valley (Valde-Nowak et al., 2014). The set of archaeological artefacts from this cave belongs to the Micoquian-Pradnik industry. Middle Palaeolithic artefacts have been discovered in several other caves, e.g. Nietoperzowa (Chmielewski, 1969, 1975; Krajcarz and Madeyska, 2010), Koziarnia (Chmielewski et al., 1967), and Wylotne (Chmielewski, 1970; Kozłowski, 2006).

The middle mesoregion of the Polish Jura Chain is referred to as the Czestochowa Upland. Madeyska (1981, 1982, 2009), Madeyska-Niklewska (1969) and Madeyska and Cyrek (2002) have worked out the geology of most caves in the Kraków- 
-Częstochowa Upland. An interesting Middle Palaeolithic site is the Biśnik Cave near Wolbrom (Cyrek, 2002; Cyrek et al., 2010, 2014; Fig.1). Its geology was studied by Mirosław-Grabowska (2002) and Krajcarz et al. (2014). The age of the sediments with Middle Palaeolithic artefacts corresponds to the Odranian (Saalian) Glaciation, the Eemian Interglacial, and the Early Vistulian (Weichselian). A well-recognized archaeological site is the Komarowa Cave in the vicinity of Olsztyn near Częstochowa (Nadachowski et al., 2009). Archaeological layers representing the Middle Palaeolithic are correlated with the Middle Plenivistulian (Interplenivistulian, MIS 3) of the Vistulian (Weichselian) Glaciation.

Another site documenting Middle Palaeolithic artefacts is the Stajnia Cave, and this is also the only locality with remains of Neanderthals (Homo neanderthalensis) in Poland. These remains were excavated within stratigraphic complex $\mathrm{D}$ and they include three permanent molars (S5000 - upper second molar, S4300 - lower first or second molar, and S4619 - upper second molar) belonging to two different adult Neanderthal individuals and one Neanderthal child (Urbanowski et al., 2010, 2012; Urbanowski, 2013; Dabrowski et al., 2013; Nowaczewska et al., 2013). This site also yielded the youngest, genetically confirmed cave bear specimen from Europe, dated to around $26.1 \mathrm{ka}$ BP (Baca et al., 2016). Due to the significance of this discovery, the sediments from the Stajnia Cave were subject to multi-proxy and high-resolution studies (Żarsk et al., 2012a, b).

The existence of Neanderthals in Eurasia is best documented from MIS 6 until MIS 3 (El Zaatari et al., 2011). They successfully survived severe climatic changes due to the Pleistocene glacial/interglacial cycles. Available palaeoecological reconstructions indicate that Neanderthals occupied different environments in Europe during the MIS 3: from cold, open habitats (e.g., Spy - Belgium), through mixed (intermediate - including vegetation elements characteristic of open and wooded environments, e.g. Saint-Césaire, France and Vindija, Croatia) to warm, wooded habitats (e.g., Lakonis, Greece and El Sidrón, Spain; El Zaatari et al., 2016).

This paper presents the results of geological, geochemical, isotope and palaeontological investigations in the Stajnia Cave. This paper is focused on recognizing the palaeoenvironmental conditions, including climate, with regard to the habitation of the cave by Neanderthals, and determining the lithostratigraphy and age of the sediments that fill the cave.

\section{GEOMORPHOLOGICAL AND GEOLOGICAL DESCRIPTION}

The Stajnia Cave is located in the Mirów Elevation, built of massive limestones, within the Jurassic Kraków-Częstochowa Upland at an elevation of $359 \mathrm{~m}$ a.s.l., between the villages of Mirów and Bobolice in the Niegowa municipality (Myszków district; Fig. 1).

The coordinates of the Stajnia Cave are $50^{\circ} 36^{\prime} 58^{\prime \prime} \mathrm{N}$, $19^{\circ} 29^{\prime} 04^{\prime \prime} \mathrm{E}$. The cave is $23 \mathrm{~m}$ long, 2-4 $\mathrm{m}$ wide and $\sim 6 \mathrm{~m}$ high, with the exposure towards the NE (Fig. $2 A-C$ ). It was formed during the Neogene and Pleistocene. Upper Oxfordian (Upper Jurassic) massive limestones are of high resistance to weather-

ing and build a rocky elevation (Fig. 2A, B, D). At the cave entrance occurs a terrace that is over $10 \mathrm{~m}$ wide, leading towards the bottom of the dry valley and covered by sands from the Vistulian (Heliasz et al., 2009; Fig. 2A, B).

The cave is filled with cave loams consisting of limestone rubble, sand, silt and clay. The rubble was formed from the weathering of limestone. Clay is also a product of limestone weathering. Sands entered to the cave from outside by aeolian processes. Sands and silts could reach the cave from the outside as a result of water transport by cracks in the ceiling of the cave.

A characteristic feature of the layers in the cave is their high discontinuity resulting from the spatial distribution in the cave, the intensity of sedimentation processes, as well as human activity from the Middle Palaeolithic until present.

\section{METHOD DESCRIPTION}

Palaeoenvironmental studies in caves require the application of interdisciplinary research methods. Basic research methods are geological specification of the type of sediment and its physical and chemical properties. These methods allow determining (approximately) the climatic conditions in which the sediments were accumulated - warm, cool or intermediate. However, they do not enable the temperature reconstruction. To infer about temperature and humidity, palaeobotanical methods can be used.

However, the frequency of pollen (and macrofossils) is insufficient in caves and we do not have a continuous record in the sediments. Pollen is often redeposited, thus palaeobotanical methods are regarded as complementary to the isotopic methods that are very important. The information about air temperature, humidity, and migration of animals and their diet is obtained from the analysis of stable oxygen isotopes content in 

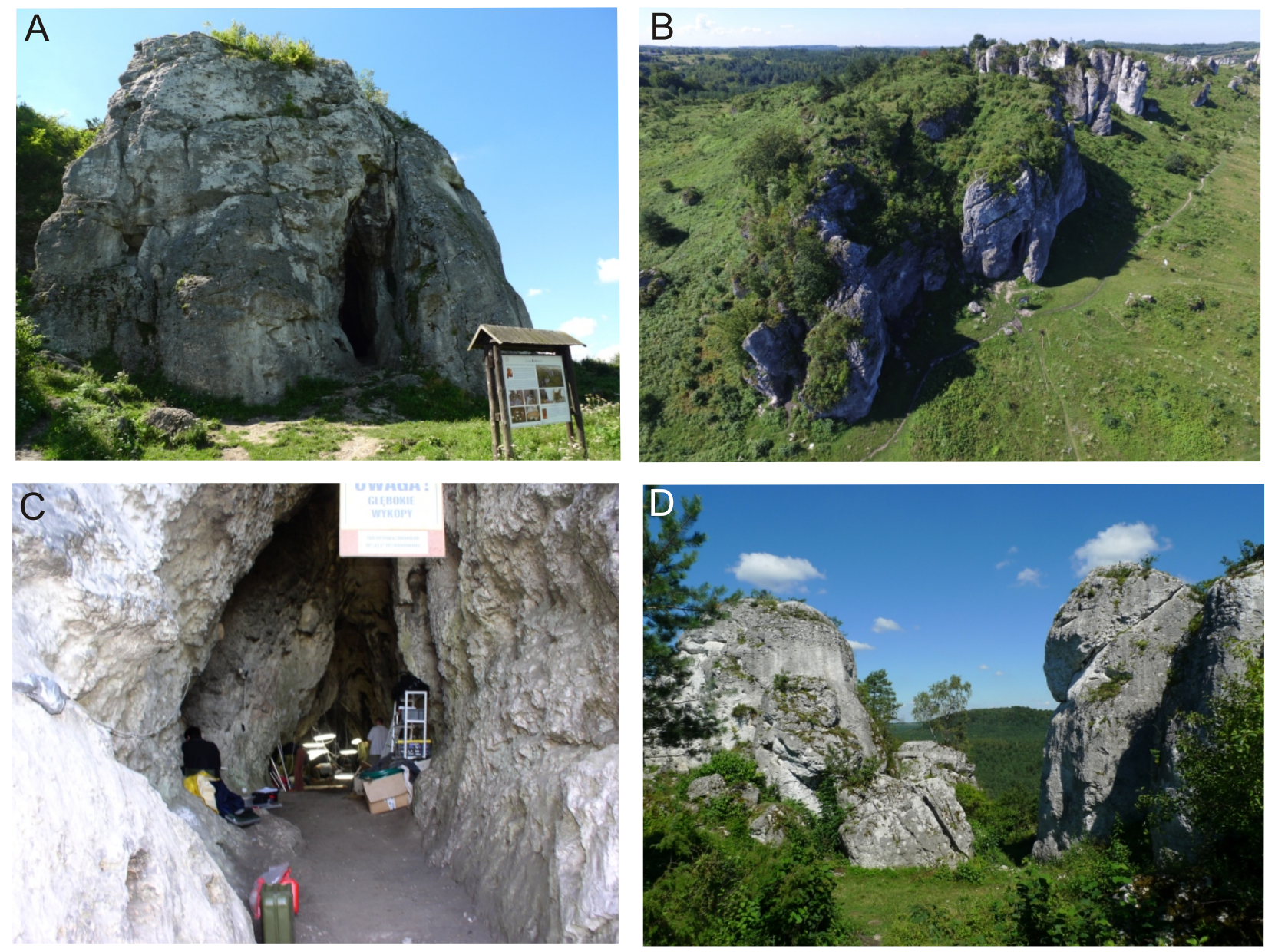

Fig. 2. Photographs showing: A-B - entrance to the cave, $C$ - interior of the cave, D - top of the Mirów Elevation above the cave (photo by Witold and Marcin Żarski)

preserved remains of animal bones and teeth. Despite the limitations of the availability of bone material in the examined layers, this method is very prospective. In the case of human fossil remains, data about palaeoclimate can be obtained based on the analysis of oxygen isotope composition of teeth. Palaeozoological methods - analysis of the species and quantity of animal bones - allow determining the palaeoenvironmental conditions concerning habitat and climate in which the animals lived. A certain limitation is the risk of redeposition of bone remains, their small frequency, and the possibility of the occurrence of particular species in different habitats. Methods of absolute dating $\mathrm{C}^{14}$, OSL and U-Th are very important complementary ones. Unfortunately, the methods of radiocarbon dating have a limited range of about 50 thousand years and are not suitable for use to very old remains and deposits. The OSL and U-Th dating methods work well to this period of time and to older remains and sediments, but to a limited extent.

Archaeological studies have allowed specifying the approximate time span.

\section{GEOPHYSICAL METHODS}

Resistivity tomography has been implemented to define the types and thickness of the cave sediments. The method is based on measuring the resistance of rocks to the flow of electric current. Each rock has a different electrical resistance. Re- sistance of limestone is $100-500 \Omega \mathrm{mm}$, of limestone rubble and loams with rubble is $1000-40,000$, and of loams without rubble is $20-100 \Omega \mathrm{mm}$ (Fig. 3).

\section{GEOLOGICAL METHODS}

Analysis of grain size composition. The following fractions $(0.250 \mathrm{~kg})$ were distinguished in the samples: large gravel $>5 \mathrm{~mm}$, gravel $2-5 \mathrm{~mm}$, sand $0.1-2 \mathrm{~mm}$, silt $0.01-0.1 \mathrm{~mm}$, and clay $0.001-0.01 \mathrm{~mm}$ (Gradziński et al., 1986). Analysis of heavy minerals composition was performed on the $0.1-0.25 \mathrm{~mm}$ fraction. The percentages of transparent and opaque minerals, which together represent $100 \%$, were determined. Analysis of calcium carbonate content in the $<0.1 \mathrm{~mm}$ fraction was made using the Scheibler method. Analysis of mineral-petrographic composition was performed for the sand fraction $(0.1-2 \mathrm{~mm})$. Analysis of frosting of quartz grains was carried out for the 0.5-1 mm fraction using the Cailleux method, modified by Goździk (1981). Analysis of limestone rubble morphology (10-20 $\mathrm{mm}$ and $>20 \mathrm{~mm}$ ) was perfomed applying the method described by Madeyska-Niklewska (1971). Analysis of mineral precipitation on limestone rubble was carried out using the EM/EDS - Scanning Electron Microscopy with X-Ray microanalysis. Geochemical analysis of cave sediments (X-ray diffraction and X-ray fluorescence) was conducted at the PGI-NRI. Geochemical analyses of the content of main and trace 
elements (ppm) of cave loams were made using an atomic absorption spectrophotometer with the application of the ICP OES method according to procedure PB-40. Analysis of organic matter content (LOS) was conducted at the PGI-NRI using procedure PB-13, edition 4 (6.11.2009), at the temperature of $1,000^{\circ} \mathrm{C}$. Analysis of humus content in the fraction $<1 \mathrm{~mm}$, using the Tiurin method, and iron content (fraction $<1 \mathrm{~mm}$ ), using the AAS method, were conducted at Wrocław University.

Archaeological excavations were the main field works in the cave. The geological samples were collected from particular layers at every $5 \mathrm{~cm}$. Individual uncovered levels in the cave were measured from the zero level corresponding to the floor of the cave. The sediments were observed in longitudinal and transverse sections. Fifteen main lithological-stratigraphic layers have been distinguished in the cave. The samples were collected from all the layers. For the total analysis of the lithostratigraphic layers, average values were used.

Pollen analyses. Fourteen samples from complexes $D$ and $C$ were subjected to pollen analysis. Samples $(0.1 \mathrm{~g})$ were collected from longitudinal and transverse sections. Laboratory processing included dissolution of calcium carbonate in $10 \%$ $\mathrm{HCl}$, boiling of the sediment in $7 \% \mathrm{KOH}$, and separation of the mineral fraction by means of heavy liquid (aqueous solution of cadmium and potassium iodide). Maceration was conducted using the modified acetolysis method after Erdtmann (1960). The results of pollen analysis were presented as a taxa check-list including ecological requirements of the taxa found, and as simplified pollen diagrams (histograms). In the calculations, the basic sum $(100 \%)$ corresponded to the pollen of trees and shrubs (AP), dwarf shrubs, and terrestrial herbaceous plants (NAP). The percentage of pollen of aquatic plants, spores, destroyed pollen, unrecognized pollen and plankton was calculated with regard to the basic sum.

Palaeozoological methods. Caves and rock-shelters, such as the Stajnia Cave, create suitable taphonomic conditions for preserving remains of both large and small vertebrates. The accumulation of fossil fauna in caves is mostly a result of natural processes such as activity of carnivores, accumulation of so-called owl pellets, with remnants of small vertebrates, or natural death. However, human behaviour can also be directly related to the use of material of animal origin, including accumulation of large bones, especially in cultural levels.

The faunal materials have been studied to extract information on environmental and climatic changes, reconstruction of past communities, as well as exploitation and utilization of remains by humans and animals. The faunal assemblages were collected during excavation (larger specimens) and by wet screening and/or sieving the sediments through small sieves. The most characteristic bones found in situ during exploration were located. Palaeontological samples were submitted to specialists for determination of skeletal categories, species and, in the case of larger bones, taphonomic modifications. Taxonomic determination of mammalian and other remains has not been finished and therefore no comprehensive quantitative and spatial analysis of the fauna is available. Also most of animal remains have not been subject of taphonomic analysis yet.

The interpretation procedures were normalized and followed widely assumed procedures, for instance:

- identification to species category, qualification of number of identified specimens (NISP) and minimum number of individuals (MNI) for each taxon in a lithologically recognized layer;

- reconstruction of dynamics and frequency of species in the stratigraphic sequence to determine faunal changes in communities and in species proportions in each layer and/or sequence;

- assessment of faunal turnover to reconstruct environmental and climatic changes during sedimentation processes.

Oxygen isotopes. Oxygen isotope composition along the enamel-dentine junction line of reindeer was investigated by SHRIMP IIe/MC ion microprobe using the secondary ion mass spectrometry (SIMS) method. The ${ }^{18} \mathrm{O} /{ }^{16} \mathrm{O}$ content expressed as $\delta^{18} \mathrm{O}$ has been used to recognize environmental input from the time of enamel formation. The SIMS (secondary ions mass spectrometry) technique does not require any chemical process during sample preparation. Selected remains of reindeer teeth including enamel were sectioned to expose the enamel/dentine junction zone. Afterwards, the tooth was positioned upon a double-sided tape together with reference apatite Durango 3 and was embedded in Struers Epofix. The introduction to in situ oxygen isotope measurements of mammalian teeth using the SIMS method was provided by Blumenthal et al. (2014). A basic instrumental configuration was described in detail by Aubert et al. (2012). According to a new analytical procedure tested on human teeth (Krzemińska et al., 2017) the sequential $\delta^{18} \mathrm{O}$ profiles have been obtained with a high spatial resolution.

The SHRIMP IIe/MC at the PGI-NRI was operated in a multi-collector negative ion mode using a $15 \mathrm{kV}, 3 \mathrm{nA} \mathrm{Cs}{ }^{+}$primary ion beam focused to a $20 \mu \mathrm{m}$ diameter spot on the Au-coated target. Oxygen isotope ratios $\delta^{18} \mathrm{O}$ are reported related to the Vienna Standard Mean Ocean Water (VSMOW) and expressed as parts per million (\%o). Analyses were corrected for a small amount of isotopically fractionated electron-induced secondary ion emission EISE (Ickert et al., 2008). The reference Durango apatite yielded a mean $\delta^{18} \mathrm{O}$ value of $9.80 \pm 0.10 \%$ o $(1 \sigma)$. The precision of each determination was usually $0.1-0.2 \%$.

\section{RESULTS}

\section{GEOPHYSICAL RESISTIVITY TOMOGRAPHY}

Three tracks were surveyed: track I in the cave, track II on the terrace in front of the cave, and track III on the terrace slope in the dry valley. Track I begins at the end of the cave, passes through its centre, and ends on the terrace. Deposits in the cave, below $1 \mathrm{~m}$ depth, were characterized by very high resistivity from 1,000 to $40,000 \Omega \mathrm{mm}$ (Fig. 3). Limestones under the terrace were characterized by the mean values of $\sim 200-500 \Omega \mathrm{mm}$. Very high resistance values correlate with the limestone rubble in the cave loams. Based on geophysical studies, it is assumed that the thickness of the sediments in the cave may reach 6-7 $\mathrm{m}$.

\section{GEOLOGY OF CAVE LAYERS}

Layer $\mathbf{H}$ was distinguished below layer $\mathbf{G}$. Orange cave loam of the uppermost part of the layer is exposed and it still awaits a geological study.

Layer $\mathbf{G}$ is composed of orange-brown sandy cave loam with low admixture of limestone rubble (Fig. 4). This layer occurs at 1.0-1.5 m below the cave base level (geodetic level)

In the grain-size composition, sand predominates over silt and clay (Fig. 5). The mineral composition of the sand fraction 


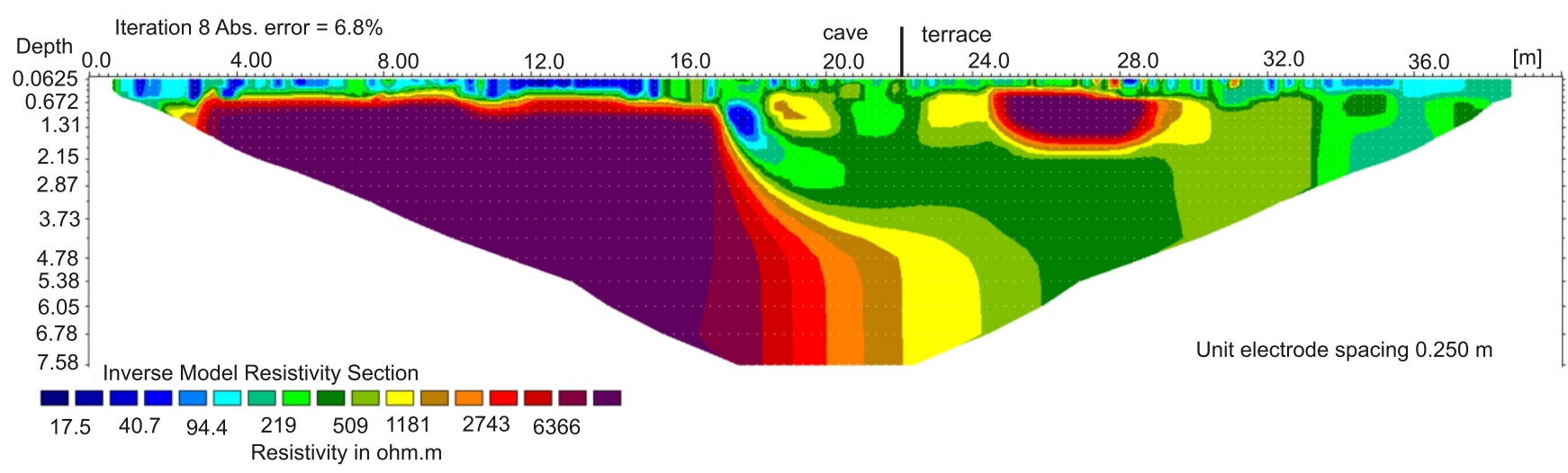

Fig. 3. Resistivity - longitudinal cross-section in the cave and terrace - track I

includes over $70 \%$ of limestones, about $28 \%$ of quartz, and $1.1 \%$ of bone fragments (Fig. 5). Morphological analysis of quartz displays the abundance of transitional shining grains $(E M / E L)$ and smaller amounts of transitional-matt grains (EM/RM), round-matt grains (RM) and fresh grains (NU) (Fig. 4). The composition of heavy minerals is dominated by opaque grains, reaching $>50 \%$ (Fig. 5). They include in situ carbonates, secondary oxides such as limonite and hematite, and primary oxides such as ilmenite and magnetite (Fig. 5). Among transparent minerals, the proportion of resistant minerals, such as tourmaline, zircon, disthene and staurolite, averagely reaches $\sim 6 \%$. The content of garnet resistant to mechanical weathering, but not resistant to chemical weathering, varied between $4.2 \%$ at the base to $24.1 \%$ at the top of the layer. The proportion of amphiboles poorly resistant to mechanical and chemical weathering reaches several percent. The main elements in layer $G$ generally include calcium, aluminum and phosphorus, ranging from 20 to $50 \%$ (Fig. 5). The content of iron is between 3.2 to $14.8 \%$. Among the trace elements from layer $\mathrm{G}$, the largest values are attained by manganese and titanium (Fig. 5). The calcium carbonate content in the $<0.1 \mathrm{~mm}$ fraction reaches several percent (Fig. 5).

Layer $\mathrm{F}$ occurs above layer $\mathrm{G}$ and more than $1 \mathrm{~m}$ below the base level of the cave (Fig. 4). It is composed of light grey, in places brown, sandy cave loam with low admixture of limestone rubble. In the grain-size composition, sand dominates over the silt and clay (Fig. 5). Among the limestone rubble, black phosphatic-calcareous concretions frequently occur. Their composition was determined based on XRD and XRF analyses. The main elements of the concretions are phosphorus and calcium. Rubble from this layer is characterized by smoothened edges (Fig. 5). The layer is dominated $(55-75.9 \%)$ by quartz grains characteristic of aeolian environments (EM/RM) (Fig. 5). Opaque minerals dominate over transparent grains, ranging from 56 to $90 \%$. Opaque minerals are dominated by in situ carbonates and secondary oxides, mainly iron compounds such as limonite and hematite (Fig. 5).

Among the transparent minerals, the proportion of garnet is from 0 to $10 \%$, and of amphiboles from 0.6 to $8.4 \%$ (Fig. 5). The percentage of minerals most resistant to weathering, such as tourmaline, zircon, disthene and staurolite, averagely reaches $\sim 4 \%$. The main elements are calcium at $47 \%$, phosphorus at $21 \%$ and aluminum at $17 \%$ (Fig. 5). The content of iron in all layers reaches $\sim 9 \%$. The highest values of trace elements are attained by manganese (52-59\%) and titanium (20\%) (Fig. 5). The content of calcium carbonate in the fraction $<0.1 \mathrm{~mm}$ varies from 1 to $5 \%$ (Fig. 5). The percentage of humus is low $-\sim 0.5 \%$ (Fig. 5).

Layer E2 belongs to complex E (layers E2 and E1) and is characterized by a higher proportion of limestone rubble (Fig. 5). It usually occurs about $1 \mathrm{~m}$ below the base level of the cave. Layer E2 is composed of brown-grey, in places black, siltyclayey-sandy loam with rubble, in which the silt and clay fractions contribute to $>50 \%$ (Fig. 5). In the mineral composition of the sand fraction, limestone dominates over quartz, crystalline rocks and bone fragments (Fig. 5). With regard to the morphology of quartz grain surfaces, layer E2 is dominated by grains indicating the aeolian environment (EM/RM, RM) compared with shining grains (EL, EM/EL) (Fig. 5). In the composition of heavy minerals, opaque minerals $(55-59 \%)$ slightly dominate over transparent minerals (Fig. 5). They include in situ carbonates (up to $50 \%$ ), secondary oxides (limonite, hematite, up to $7 \%$ ) and primary oxides (ilmenite, magnetite, up to $15 \%$ ). Among transparent minerals, the percentage of garnet is $>10 \%$. The proportion of each mineral very resistant to weathering, such as tourmaline, zircon, disthene and staurolite, averagely reaches several percent. The main elements are dominated by calcium (up to $53 \%$ ), followed by iron, aluminum and phosphorus ( 10\%; Fig. 5). Trace elements are dominated by manganese (17-34\%; Fig. 4). The content of calcium carbonate in the $<0.1$ $\mathrm{mm}$ fraction is from 0.7 to $12.2 \%$ (Fig. 4).

Layer E1 - grey cave loam - occurs above layer E2 and usually $1 \mathrm{~m}$ below the cave base level (Fig. 4). It is characterized by a high proportion of limestone rubble and a thickness of $\sim 50 \mathrm{~cm}$, in which rubble contributes to $>70 \%$ (Fig. 5). A characteristic feature is the vertical percentage fluctuations of all fractions. Layer E1 is dominated by partly smoothened rubble with an admixture of smoothened and sharp-edged rubble (Fig. 5). The rubble surfaces are often covered by corrosion cavities and manganese-phosphate precipitates. In the mineral composition of the sand fraction, like in the underlying layers, limestone predominates over quartz, bone fragments and iron-manganese concretions (Fig. 5). In layer E1, quartz with aeolian reworking (EM/RM and RM grains) dominates over shining grains (EM/EL) (Fig. 5). Angular grains (NU) contribute to $\sim 12 \%$. Heavy minerals show slight predominance of opaque minerals (limonite, hematite, ilmenite and magnetite) over transparent grains (garnets, amphiboles, tourmaline, zircon, disthene and staurolite; Fig. 5). Layer E1 is relatively uniformly developed with regard to the main elements, whose percentage values do not reveal variability in the vertical section (Fig. 5). The average content of calcium is $\sim 50 \%$, aluminum $-17 \%$, phosphorus - 


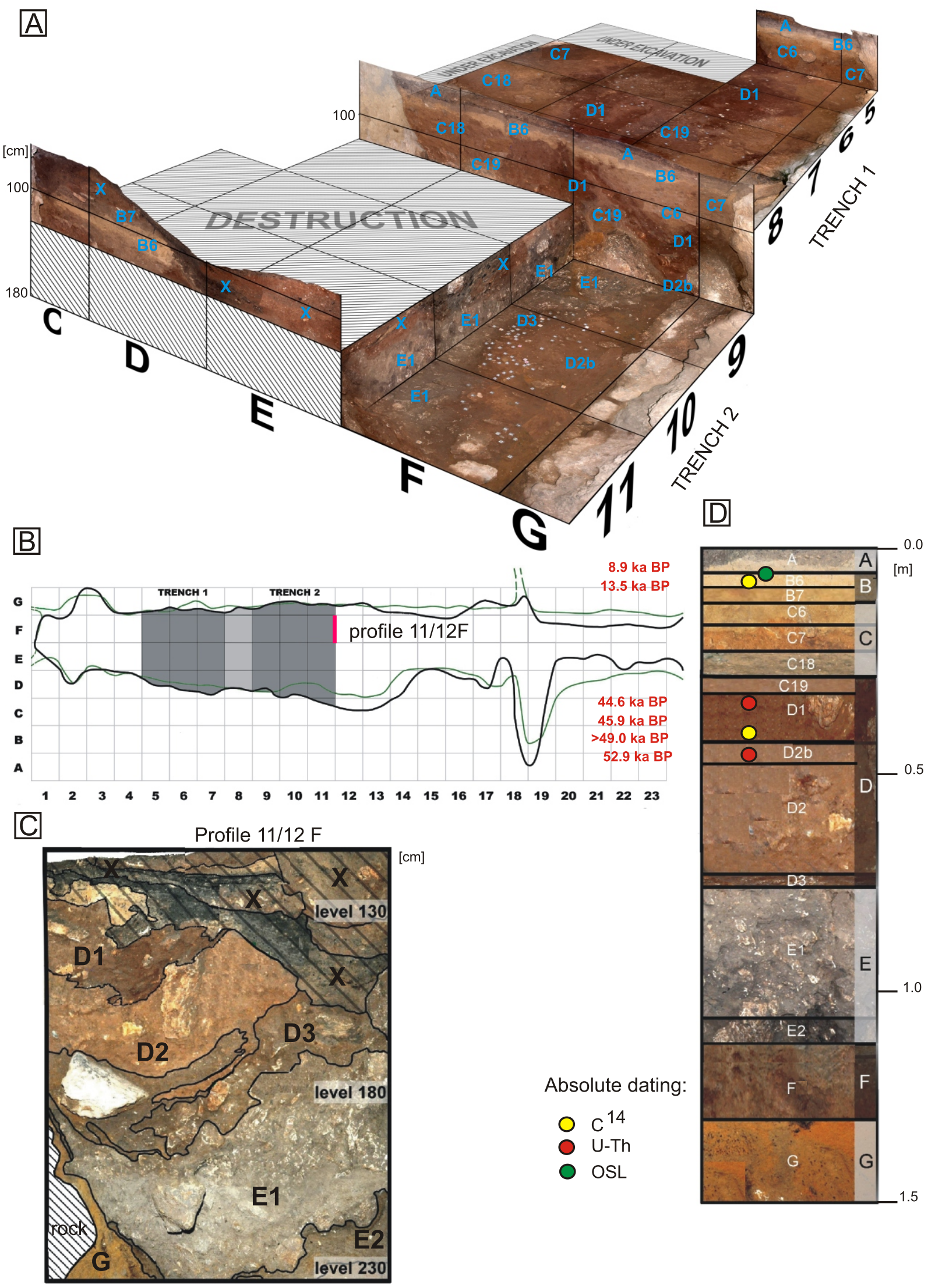

Fig. 4. Geology of the cave

A - 3D visualization of the geological structure, D1 - lithostratigraphic layers; B - plan of the cave with marked trenches (grey) and profile (red line); C - profile 11/12F; D - simplified lithostratigraphic column of the layers in the cave 

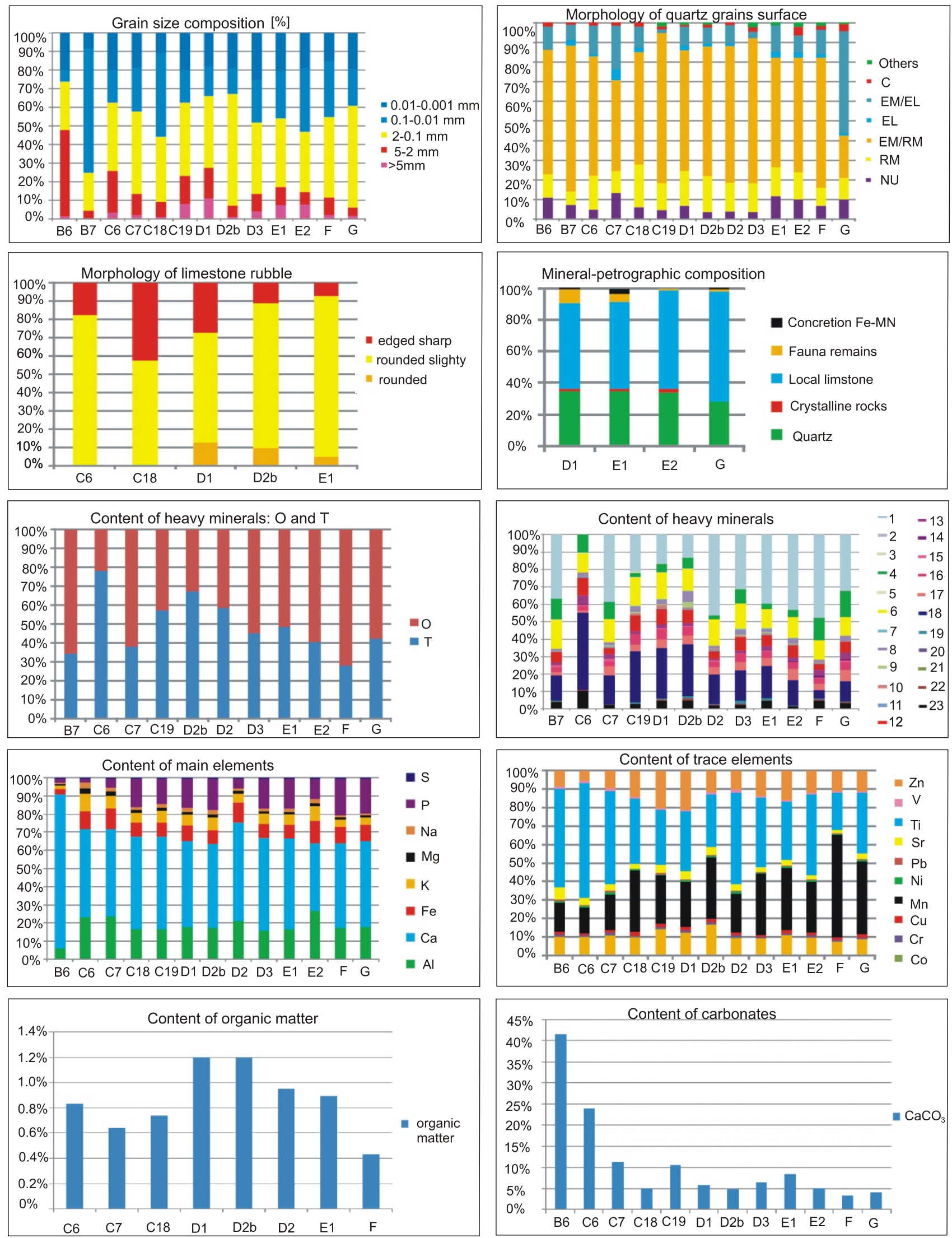

Fig. 5. Laboratory results of grain-size composition, morphology of quartz grains surface, morphology of limestone rubble , mineral-petrographic composition, and the contents of opaque $(O)$ and transparent $(T)$ heavy minerals, heavy minerals, main and trace elements, organic matter, and carbonates

1 - carbonate in situ, 2 - pyroxene, 3 - muscovite, 4 - second oxides, 5 - glauconite, 6 - primary oxides, 7 - siderite, 8 - topaz, 9 - apatite, 10 - sillimanite, 11 - andalusite, 12 - staurolite, 13 - disthene, 14 - titanite, 15 - rutile, 16 - zirconium, 17 - tourmaline, 18 - garnet, 19 epidote, 20 - chlorite, 21 - biotite, 22 - pyroxene, 23 - amphibole 
$16.5 \%$, and iron $-7.5 \%$. Among trace elements, small oscillations can be observed in the vertical section (Fig. 5). The average percentage of manganese and titanium is $\sim 30 \%$, barium and zinc $->10 \%$. The percentage of carbonates varies from 5 to $14 \%$. The content of humus is low and does not exceed $1 \%$.

Layer D3 is a dark brown sandy-silty-clayey cave loam with an admixture of fine limestone rubble. It belongs to complex D (D3, D2, D2b and D1) being of the highest archaeological significance due to the abundance of flint artefacts from the Middle Palaeolithic and Neanderthal teeth (layers D2-D1; Figs. 4 and 6).

The layer has a small thickness of $\sim 30 \mathrm{~cm}$ and is located above layer E1, not more than $1 \mathrm{~m}$ below the cave base level. The layer is dominated by sand $(\sim 40 \%)$, clay $(25 \%)$ and silt $(\sim 23 \%)$ (Fig. 5). Analysis of the morphology of quartz grains indicates the dominance of quartz grains with aeolian reworking (EM/RM and RM), and an admixture of transitional shining (EM/EL), fresh (NU) and crushed (C) grains (Fig. 5). Opaque heavy minerals dominate over transparent minerals (Fig. 5). As in all previously described layers, opaque minerals are dominated by in situ carbonates ( $30 \%$; Fig. 5). The content of secondary oxides (limonite, hematite) is $\sim 8 \%$, and of primary oxides (ilmenite, magnetite) $-\sim 15 \%$. Among transparent minerals, the content of garnet is relatively low and reaches $\sim 17 \%$ (Fig. 5). Also the percentage of amphiboles is low - up to $\sim 2 \%$. The content of minerals very resistant to destruction, such as tourmaline, zircon and staurolite, reaches $\sim 5 \%$, whereas the contents of disthene and topaz do not exceed $3 \%$. The main elements are dominated by calcium $(\sim 50 \%)$ (Fig. 5). The content of aluminum and phosphorus is $>10 \%$, and iron and potassium $-6-7 \%$. Among trace elements, manganese and titanium are predominant (Fig. 5). The carbonate content is $5.4 \%$ (Fig. 5).

Layer D2 is located directly below layer D1. It is a light brown cave loam with rubble (interval $155-220 \mathrm{~cm}$; Fig. 4). Analysis of the morphology of quartz grains has revealed abundance of EM/RM and RM ( $80 \%)$ and more than $10 \%$ of EM/EL grains (Fig. 5). Opaque heavy minerals (mainly primary and secondary oxides) prevail over transparent grains (Fig. 5) among which the average content of garnets is $\sim 17 \%$ (Fig. 5). The content of amphiboles in the analysed samples is low and relatively uniform, varying at $1-3 \%$. The contents of minerals resistant to weathering (tourmaline, zircon, staurolite and disthene) are around several percent. The main elements are dominated by calcium (>50\%, Fig. 5). Among trace elements, the manganese content is up to $20 \%$ (Fig. 5). The content of

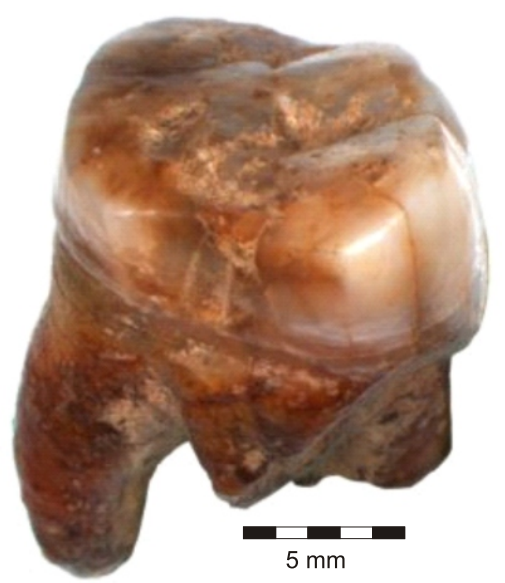

Fig. 6. Stajnia Cave, layer D2 (specimen 5000 - Neanderthal upper second molar) carbonates reaches $\sim 5.5 \%$ (Fig. 5). The content of humus is $\sim 1 \%$ (Fig. 5).

Layer D2b is a light brown sandy-clayey-silty cave loam with limestone rubble. Sand predominates over clay and silt in the grain-size composition (Fig. 5). The layer is dominated by partly smoothened rubble $(-80 \%)$ and smoothened rubble (10\%), whereas sharp-edged rubble comprises $\sim 10 \%$ (Fig. 5). Corrosion cavities occur in the rubble and it is often covered by manganese-phosphate precipitates. Among quartz grains, aeolian grains (EM/RM, about $65 \%$ ) dominate over transitional shining grains (EM/EL) (Fig. 5). Transparent heavy minerals dominate over opaque minerals, and they are represented mainly by garnet ( 30\%; Fig. 5). Amphiboles have not been encountered in this layer. The remaining minerals are very resistant to weathering: tourmaline, zircon, staurolite, apatite and topaz, reaching values of a few percent. Among opaque heavy minerals, in situ carbonates, and secondary and primary oxides dominate (Fig. 4). The main elements are dominated by calcium $(46.2 \%)$. The content of aluminum and phosphorus is $10 \%$, and the content of iron and potassium is several percent (Fig. 5). Trace elements are dominated by manganese ( 34\%; Fig. 5). The content of carbonates in the layer reaches $\sim 5 \%$, and of humus $-\sim 1 \%$ (Fig. 5 ).

Layer D1 - a light brown cave loam with rubble - is the main archaeological horizon with the greatest abundance of artefacts from the Middle Palaeolithic (Fig. 4). Its thickness is up to $0.5 \mathrm{~m}$. Sand dominates $(\sim 40 \%)$ over clay, silt and gravel in the grain-size composition, exceeding $10 \%$ (Fig. 5). The layer is dominated by partly smoothened rubble $(60 \%)$ with admixture of smoothened rubble $(13 \%)$ and a slightly higher proportion of sharp-edged rubble (27\%; Fig. 5). The surfaces of the rubble are smooth, although rubble with corrosion cavities and manganese-phosphate precipitates is also present. The mineral composition of the sand fraction is dominated by limestones, locally at $43-64 \%$ (Fig. 5). The content of quartz varies from 26 to $49 \%$. The percentage of faunal remains varies from 1.5 to $18 \%$. The remaining part comprises crystalline rocks and Fe-Mn concretions. Quartz grains with aeolian reworking (EM/RM and RM) contribute to $80 \%$ (Fig. 5). EM/EL and EL grains, characteristic of aqueous transport, reach a total of $\sim 10 \%$. The contribution of heavy minerals in the vertical section is uniform. Transparent minerals (64\%), with prevalent garnet $(30 \%)$, dominate over opaque minerals (36\%; Fig. 5). The content of amphiboles varies from 3 to $9 \%$. The proportion of minerals very resistant to weathering (e.g., tourmaline, zircon, staurolite, disthene, topaz and sillimanite) reaches several percent. Opaque minerals are dominated by in situ carbonates ( 15\%; Fig. $5)$. Secondary oxides, mainly iron compounds (limonite, hematite) and primary oxides (ilmenite, magnetite), contribute to $\sim 5 \%$. The geochemical characteristics of layer D1 are rather uniform in vertical profile. The main elements are dominated by calcium - $48 \%$, followed by $18 \%$ of aluminum, $16 \%$ of phosphorus, and $8 \%$ of iron (Fig. 5). Among trace elements, the content of manganese reaches $\sim 24 \%$, titanium $-32 \%$, zinc $-20 \%$, and barium $-12 \%$ (Fig. 4 ). The content of carbonates is $\sim 6 \%$ (Fig. 5). Humus accounts for $\sim 1 \%$ (Fig. 5).

Layer C19 - grey cave loam with red streaks and limestone rubble is a discontinuous horizon occurring above layer D1, lying $<1 \mathrm{~m}$ below the cave base level (Fig. 4). The proportion of sand is $\sim 40 \%$ (Fig. 5). Gravel, silt and clay account for $20 \%$ each. Analysis of the rubble morphology indicates similar proportions of smoothened rubble, with cavities after chemical etching, and sharp-edged rubble (Fig. 5). All limestone fragments are densely coated with a mineral-clay matrix, partly carbonate, with quartz grains and occasional fine yellow bone fragments that are mineralized and polished. The sediments are 
uniform with regard to reworking of quartz grains. EM/RM and RM grains prevail, accounting for $\sim 90 \%$ of all grains (Fig. 5). Transparent heavy minerals $(\sim 57 \%)$, with prevailing garnets $(\sim 30 \%)$, predominate over opaque minerals (Fig. 5). The content of amphiboles is $\sim 3 \%$. The proportion of minerals most resistant to weathering, such as tourmaline, zircon, staurolite, disthene, topaz and sillimanite, does not exceed $10 \%$ each. Opaque minerals are dominated by in situ carbonates, secondary and primary oxides (Fig. 5). The content of main elements is relatively uniform (Fig. 5), with the prevalence of calcium, as in the remaining layers ( $50 \%$; Fig. 5). The content of phosphorus is $\sim 14 \%$, and iron $-\sim 8 \%$. Trace elements are dominated by manganese ( $25 \%$; Fig. 5). The average content of titanium and barium is $\sim 13 \%$. The proportion of carbonates is relatively high and reaches $\sim 12 \%$ (Fig. 5).

Layer C18 - light grey silty-sandy cave loam with limestone rubble occurs below complexes $\mathrm{C}$ and $\mathrm{B}$ (Fig. 4). According to recent studies, the structure of this layer was most probably subject to anthropopression. Silt $(\sim 45 \%)$ predominates over sand, clay and gravel in the grain-size composition (Fig. 5). Partly smoothened limestone rubble prevails in the layer (50\%), with a very high percentage of sharp-edged rubble $-42 \%$ (Fig. 5). $\mathrm{EM} / \mathrm{RM}+\mathrm{RM}$ grains prevail, accounting for $\sim 80 \%$ in total (Fig. 5). The main elements are dominated by calcium ( $50 \%)$ with an admixture of aluminum and phosphorus (over several percent each), and iron and potassium (slightly $>5 \%$; Fig. 5). Among trace elements, the main elements are titanium and manganese, reaching $\sim 34 \%$ each (Fig. 5). The content of carbonates is up to $\sim 5 \%$, and humus $-<1 \%$ (Fig. 5 ).

Layer C7 - brown-yellow cave loam - is usually located close to the cave walls and several tens of centimetres below the cave base level (Fig. 4). Sand ( $45 \%)$ predominates over silt, clay and gravel in the grain size composition (Fig. 5). EM/RM and RM grains prevail, reaching a total of $\sim 60 \%$ (Fig. 5). There is a high admixture of quartz grains with transitional-shining surfaces (EM/EL, $\sim 23 \%$ ). Heavy minerals are dominated by opaque minerals: in situ carbonates, and secondary and primary oxides, up to $\sim 62 \%$ (Fig. 5). Garnet dominates among transparent minerals ( $17 \%$; Fig. 5). The content of minerals most resistant to weathering is several percent each and does not exceed $5 \%$. The geochemical composition is relatively uniform. Calcium prevails among the main elements ( $48 \%$; Fig. 5). The content of iron is $\sim 11 \%$, and of phosphorus $-5 \%$. Trace elements are dominated by titanium ( $\sim 5 \%$; Fig. 4). The content of manganese is $19 \%$, barium $-10 \%$, and zinc $-9 \%$. The content of carbonates is $\sim 11 \%$, and humus $-<1 \%$ (Fig. 5).

Layer C6 - yellow sandy cave loam with rubble - occurs above layer $\mathrm{C} 7$, several tens of centimetres below the cave base level (Fig. 4). The grain-size composition is relatively uniform. The content of sand is $\sim 37 \%$, clay and silt $-\sim 20 \%$ each, and gravel $-\sim 25 \%$ (Fig. 5). Partly smoothened rubble dominates in the layer, with an admixture of sharp-edged rubble (Fig. 5). Single rubble fragments with cavities and manganese-ferruginous covers on the surface also occur. The proportion of EM/RM and RM grains reaches up to $80 \%$ in total, with a $15 \%$ content of EM/EL grains (Fig. 5). Transparent heavy minerals dominate over opaque minerals (Fig. 5), and the most common transparent mineral is garnet $(\sim 45 \%)$, with a relatively high content of amphiboles ( $10 \%$; Fig. 5). The proportion of minerals very resistant to weathering (tourmaline, zircon, staurolite, disthene and topaz) is relatively low and reaches several percent each. In situ carbonates have not been found among the opaque minerals (Fig. 5). The proportion of secondary oxides (limonite, hematite) and primary oxides (ilmenite, magnetite) is up to $10 \%$ each. The main elements are dominated by calcium $(\sim 40 \%)$. Iron ( 7\%) and phosphorus (3\%; Fig. 5) are found in low amounts. Trace elements are dominated by titanium $(-63 \%$; Fig. 5$)$. The proportion of manganese is $13 \%$, barium $9 \%$, and zinc $-5 \%$. The content of carbonates is high and reaches $\sim 24 \%$, and of humus $-<1 \%$ (Fig. 5).

Layer B7 - yellow silty-sandy cave loam with limestone rubble, in places with interbeds of sand - lies from over ten to several tens of centimetres below the cave base level (Fig. 4). The grain-size composition is dominated by silt ( $67 \%)$ accompanied by $\sim 20 \%$ of sand (Fig. 5). EM/RM and RM grains dominate at $\sim 80 \%$ (Fig. 5). Opaque heavy minerals prevail over transparent minerals (Fig. 5), and are dominated by in situ carbonates at $\sim 37 \%$, followed by secondary (limonite, hematite) and primary oxides (ilmenite, magnetite; Fig. 5). Transparent minerals are dominated by garnet ( 14\%; Fig. 5). Minerals very resistant to weathering (staurolite, tourmaline, zircon and disthene) contribute to several percent each.

Layer B6 - yellow sandy cave loam with a high proportion of limestone rubble - occurs at $>10 \mathrm{~cm}$ below the cave base level (Fig. 4). The grain-size composition is dominated by gravel $(\sim 50 \%)$, followed by sand $(\sim 25 \%)$, clay $(30 \%)$ and silt ( $\sim 5 \%$; Fig. 5). EM/RM and RM grains dominate at $\sim 75 \%$, with a proportion of EM/EL and NU grains at $\sim 10 \%$ each (Fig. 5). The main elements are dominated by calcium ( $85 \%$; Fig. 5). Aluminum, iron, potassium and phosphorus contribute to several percent each. Trace elements are dominated by titanium, accompanied by barium and zinc (Fig. 5). The proportion of carbonates is high and reaches $\sim 42 \%$ (Fig. 5).

Layer A comprises grey-black humus with limestone rubble (Fig. 3). Geological investigations have not been conducted in this layer. Its average thickness ranges from several to several tens of centimetres.

Anthropogenic structures " $X$ " also occur in the cave. They are commonly represented by excavations that cut across the main layers B and C (Fig. 4). These are mainly pits filled by redeposited cave loam with humus, usually dark grey to black in colour.

\section{THE IMPORTANCE OF GEOLOGICAL ANALYSES FOR PALAEOENVIRONMENTAL INTERPRETATION}

Grain-size composition. The clay fraction develops mainly as a result of chemical weathering, which increases with the rise of temperature (Madeyska-Niklewska 1971; Madeyska 2009). The highest contents of the clay fraction exceeding $20 \%$ are observed in layers D3 and E1, and the lowest ones in layers B7 and $\mathrm{C} 18$. It can be concluded that layers D3 and E1 were accumulated in slightly warmer conditions, and layers B7 and C18 in colder conditions. Silt was supplied to the cave sediments by blowing in during periglacial conditions, but its transport by water dribbling along the fractures from the surface is also possible. A higher proportion of silt in the layers may also reflect cooler climate conditions during sedimentation (Madeyska, 1982, 2009). The highest contents of silt are observed in layers B7, C18 and E2, from 34 to $67 \%$, and the lowest - in layers D1, $\mathrm{D} 2 \mathrm{~b}$ and $\mathrm{B} 6$, from 6 to $14 \%$. The average content of sand in the layers is $20 \%$. A higher content $(60 \%)$ is observed only in layer D2b. Sand could be transported to the cave by wind in a dry and cold climate, and by fluvial transport in a more humid climate.

The limestone rubble in the sediments is mainly the result of mechanical weathering of limestones in a cold climate (Madeyska, 1971). The highest proportion of large rubble $>20 \mathrm{~mm}$ is 
observed in layers E1, E2, B6, and D1. The lowest rubble content is observed in layers $\mathrm{G}$ and D2b; slightly warmer climate conditions prevailed at the time of their formation.

Morphology of limestone rubble. Partly smoothened limestone rubble prevails in the sediments from all layers, which indicates similar climate conditions during their accumulation. Layers D1, D2b and E1 contain $\sim 10 \%$ of smoothened rubble, which may indicate slightly warmer climate conditions (Madeyska, 1969, 1971, 1982). The highest percentage of sharp-edged rubble is observed in C18 (>40\%), which indicates low temperature during deposition of this layer. In D1, D2b, E1 and $F$, the limestone rubble surface is covered by manganese-phosphate and ferruginous precipitates that formed as a result of chemical weathering in a relatively warm climate.

Mineral-petrographic composition. Upper Jurassic limestone prevail (from 55 to $70 \%$ ) in the sand fraction of the studied samples. This is the result of mechanical weathering of limestones, in which the cave developed. The proportion of quartz grains reaches $\sim 30 \%$ in all layers. Quartz is an external component and was transported by aeolian and fluvial processes. The admixture of crystalline rocks, which were also transported from the surroundings to the cave, did not exceed $2 \%$. Layers D1 and E1 contain a greater admixture of animal bones.

Morphology of quartz grains. Matt and half-matt (RM and $E M / R M)$ grains dominate in the investigated layers $-70 \%$, with the exception of layer $\mathrm{G}$, in which shining and transitional shining grains prevail ( $53 \%)$, characteristic of fluvial sedimentation. Such results indicate intense aeolian activity in a dry and cool climate (Woronko, 2001; Mycielska-Dowgiałło, 2007). The prevalence of shining grains in layer $\mathrm{G}$ points to a more humid and probably warmer climate. The proportion of crushed grains $\mathrm{C}$ and angular grains NU in all layers is $\sim 2$ and $7 \%$, respectively. Such grains prove mechanical weathering in a very cold climate.

Heavy minerals. The content of opaque heavy minerals (in situ carbonates and oxides, being compounds of iron) reaches $>50 \%$ in layers G, F, E2, E1, D3, D2, C7 and B7. In layers D2b, D1, C19 and C6, transparent minerals dominate.

Opaque heavy minerals originated due to chemical weathering in more humid conditions and probably at slightly higher temperature (Barczuk and Nejbert, 2007; Marcinkowski and Mycielska-Dowgiałlo, 2013). The prevalence of these minerals may point to a more humid climate. Transparent heavy minerals were derived from outside the cave. Their origin is related to weathering of sediments occurring beyond the cave. High values of transparent minerals probably indicate that the host sediments originated in a cold and dry climate. Garnet prevails among transparent heavy minerals; it is more resistant to mechanical weathering but less resistant to chemical weathering (Marcinkowski and Mycielska-Dowgiałlo, 2013). Lower garnet contents $(\sim 20 \%)$ are observed in layers B7, C7, D2, and in layers D3, E1, E2, F, G. Such values may indirectly point to a more humid climate and possibly to slightly higher temperatures. In layers D2b, D1, C19, C6, and B6, in which the garnet content is $\sim 30 \%$, the climate was probably drier and cooler. The content of minerals non-resistant to weathering, such as: glauconite, biotite, pyroxene, muscovite and amphiboles, is low in all layers. Low oscillations of the content of these minerals in the sediments may indicate small climate oscillations during the accumulation of the layers. Heavy minerals show a significant proportion of minerals very resistant to weathering, such as zircon (2-6\%), tourmaline $(2.0-6.7 \%)$, topaz $(1-6 \%)$ and staurolite (7-10\%). With garnet, these minerals have the highest percentage content among transparent minerals. A significant amount of transparent heavy minerals that are resistant to weathering points to numerous redeposition events of the sediments, mainly due to aeolian transport (Marcinkowski and Mycielska-Dowgiałło, 2013).

Main elements. The dominant element in all layers is calcium, with the average content of $>50 \%$. The highest calcium content occurs in layer B6 - 85\%, and the lowest (37\%) in layer E2. The higher calcium content may indicate a drier climate, and a lower content - a more humid climate, because calcium is well-dissolved in water (Migaszewski and Gałuszka, 2007). The average content of aluminum in the layers is $\sim 17 \%$. Aluminum was transported into the cave from the outside. Small differences in the aluminum content in particular layers indicate similar sedimentation conditions. The average phosphorus content in the layers is $>10 \%$. Phosphorus is derived mainly from the destruction of bone fragments and faeces animals, and due to chemical weathering (Homsey and Capo, 2006; Migaszewski and Gałuszka, 2007). The lowest percentage content of phosphorus is noted in layers B6 and C6: 2.3 and $2 \%$, respectively, and in layers C7 and D2: 5 and $\sim 6 \%$, respectively, which may indirectly indicate a cooler and drier climate with a decreased number of animals. In the remaining layers the phosphorus content varies from $>10$ to $20 \%$. The lowest iron content is noted in layers $\mathrm{B} 6-\sim 3 \%$. In the remaining layers, it ranges from 8 to $11 \%$. The iron content in the cave sediments is higher than in the massive limestones, in which the cave is developed (Żarski et al., 2012a). Enrichment of sediments in iron took place by aeolian and fluvial transport from outside the cave. The potassium content was several percent in each layer. Potassium was also supplied to the cave from the outside. It developed due to the weathering of rocks containing feldspars and micas (Migaszewski and Gałuszka, 2007), such as fluvioglacial sediments. The content of sodium and magnesium in all layers was $\sim 2 \%$. Sodium was also transported from outside the cave and formed due to feldspar weathering. Magnesium is derived from the dissolution of limestones in a high-humidity environment (Migaszewski and Gałuszka, 2007). The low magnesium content may point to relatively low humidity of the climate during sedimentation. Small differences in the content of trace elements in particular layers indicate similar climate conditions during sedimentation.

Trace elements. The dominant trace element is titanium. Its highest values of $50-60 \%$ are noted in layers B6, C7, and C6, and $\sim 44 \%$ in layer E2. The lowest titanium contents are found in layer $\mathrm{F}$ - $\sim 20 \%$. In the remaining layers the titanium content is $\sim 30 \%$. Titanium originated due to mechanical weathering mainly of iron minerals in a cold climate. Higher titanium values indicate a colder climate, whereas lower - a warmer climate (Żarski, 2012a). The highest manganese values $(40-55 \%)$ are noted in layers $F$ and $G$, and the lowest (>10\%) in layers B6, C7 and C6. In the remaining layers the manganese content is $\sim 30 \%$. Higher manganese values may be correlated with a slightly warmer and more humid climate, because manganese is the product of chemical weathering of limestones (Mirosław-Grabowska, 2002; Migaszewski and Gałuszka, 2007). The lowest zinc proportions (-8\%) are noted in layers C6 and C7. In the remaining layers the content is $>10 \%$. Higher zinc values indicate more humid climate conditions, while smaller - drier conditions (Żarski et al., 2012a).

Calcium carbonate. The contents of calcium carbonate in layers B6, C6, C7, and C19 are $\sim 40,24$ and $10 \%$, respectively. In the remaining layers the values are of several percent. High quantities of calcium carbonate may be correlated with a colder climate (Żarski et al., 2012a).

Humus. The humus content in particular layers is $<1 \%$ with the exception of layers D1 and D2, where the values exceed $1 \%$. It may be related to the habitation of the cave by humans (Madeyska, 1981). 


\section{POLLEN ANALYSIS}

The pollen record was obtained from layers D1, D2, C19, C18, C6 and C7. The remaining layers have yielded no pollen, but they contain charcoals pointing to the habitation of Neanderthals in the cave. The presence of pollen should be related to calcium carbonate deposition. The pollen spectra from the analysed samples have variable pollen content, i.e. from 100 to 1000 and more, and a different preservation state. All samples are characterized by the presence of strongly destroyed pollen, with an effaced morphology, impossible to identify. Tricolpate and tricolporate pollen was particularly prone to destruction processes, which prevents their identification. High degree of pollen destruction negatively influences the possibility of precise palaeoenvironment reconstruction and indicates deposition in aerobic conditions. Besides such sporomorphs, there were numerous with a lower degree of destruction, identified to the family level, for instance Caryophyllaceae and Asteraceae pollen.

The frequency of pollen in the samples from the sediments collected at Stajnia Cave is variable, but significantly high, and the specimens are well-preserved in comparison to other caves from the Kraków-Częstochowa Upland (Fig. 1). As indicated by investigations of cave sediments (Navarro et al., 2001), pollen assemblages could reflect vegetation of both local and regional catchment areas. However, the variability of pollen assemblages may also result from cave geometry, sedimentary processes and sediment humidity. Moreover, similarly as in other caves, there is no correlation between the bed structure, intensity of chemical processes, or proportion of coarse material (Carrión, 1995). With regard to the Stajnia Cave, the source of pollen in the studied sediments, besides the natural presence resulting from aqueous transport and blowing in, was human activity and presence of animals. Plant pollen was carried on clothes, and could also derive from plants collected in the cave for different purposes (Lityńska-Zając and Wasylikowa, 2005).

Spectra from samples no. 6 (layer C7) and no. 14 (layer C18) contain pollen of Tsuga, Carya, Sciadopitys, Nyssa and Liquidambar, and a few Dinoflagellata cysts. The presence of these taxa should be related to their infiltration from older sediments to Pleistocene strata by aqueous transport. Among the taxa, pollen of plants pollinated by animals prevails, which may indicate sedimentation in aqueous settings (Lityńska-Zając and Wasylikowa, 2005).

The pollen diagram (Fig. 7) was subdivided into three levels. Pollen spectra of all three levels are dominated by NAP (terrestrial herbaceous plants and dwarf shrubs), represented mainly by the Cichorioideae with values up to $70 \%$. A high proportion of Cichorioideae pollen is observed in Palaeolithic layers of many caves (Lityńska-Zając and Wasylikowa, 2005 after Groner, 1985; Leroi-Gourhan, 1997). The overrepresentation of this pollen in cave sediments has not been explained until present. One of the possible reasons is the resistance to destruction and selective decomposition, but it may also be related to specific transportation and sedimentation conditions in the caves (Groner, 1985). Another possible source of Cichorioideae pollen in caves as plants pollinated by insects is animal faeces, mainly of bats (Dimbleby, 1985).

Other abundant taxa include pollen of Helianthemum, Anthemis t., Asteraceae, Apiaceae, Poaceae, Caryophyllaceae, Cirsium t., Brassicaceae, Artemisia, Ericaceae and Cheonopodiaceae (Fig. 7). Tree pollen belongs mainly to Betula and Pinus sylvestris t. Pollen of other trees occurs sporadically. Numerous are also spores of Filicales monolete and others, including Sphagnum (Fig. 7).

Level I (layer D2) is dominated by Cichorioideae pollen, but pollen of the Poaceae, Asteraceae, Anthemis and Cirsium types is also numerous. Trees are represented by Pinus and
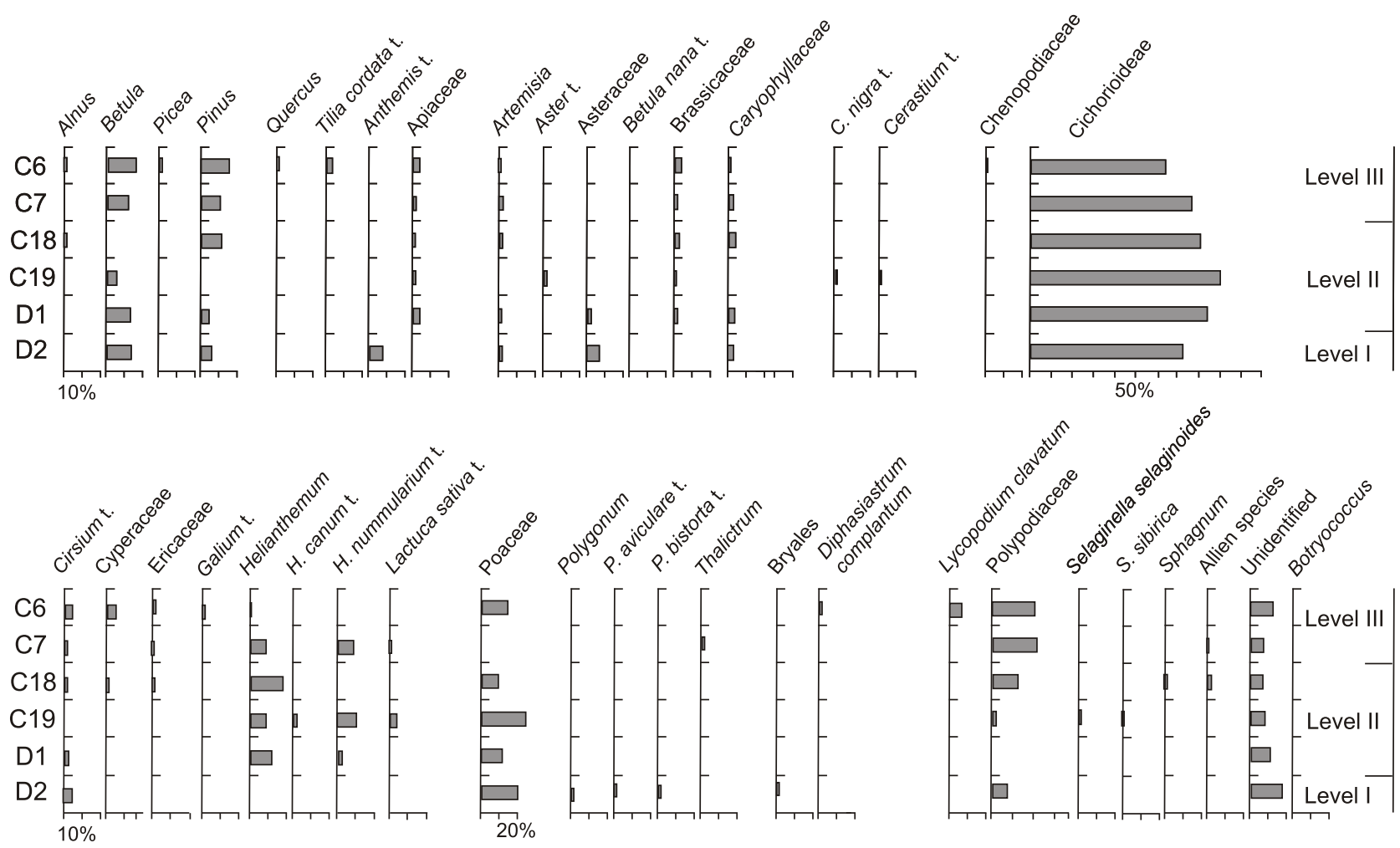

Fig. 7. Pollen diagram 
Betula pollen. In level II (layers D1, C19, C18), Cichorioideae pollen is predominant with the proportion exceeding $70 \%$. The percentage content of Helianthemum (up to $20 \%$ ), Poaceae, Caryophyllaceae and Brassicaceae also rises. In layer C18, there is a decrease in the values of Cichorioideae and an increase in the proportion of Pinus and Betula pollen. Changes that began in layer $\mathrm{C} 18$ are much more distinctly manifested in level III (layers C7 and C6). The values of Cichorioideae and Caryaophyllaceae clearly decrease, and the pollen of Helianthemum disappears. The abundance of Cyperaceae, Apiaceae and Brassicaceae rises, as well as that of Cirsium type. Worth noting are the increased values of pollen of Pinus and Picea coniferous trees, and rising pollen of deciduous trees with higher temperature requirements - Tilia cordata type and Quercus.

The taxonomic composition of this pollen flora (Table 1) indicates that the pollen assemblages may reflect local vegetation to a certain degree, but are also disturbed due to human and animal activity. This is testified by the large values of Cichorioideae pollen, although the high proportion of these plants in the local vegetation also cannot be ruled out. Similarly high values of this pollen, reaching $60 \%$, have been noted in the
ODP Leg 161 Site 976 that was drilled in the Alboran Sea (Combourieu Nebout et al., 2009). This may indicate the possible occurrence of natural habitats of open vegetation with very high proportion of representatives of the Cichorioideae.

Dominance of NAP pollen and taxonomic variability of herbaceous plants in level II indicate the presence of different habitats of open vegetation and their patchwork character. The presence of steppe-like habitats in dry areas is evidenced by pollen of Helianthemum, Artemisia, Aster t., and various species of Centaurea (C. jacea t., C. nigra t., C. cyanus). Humid habitats supplied pollen of the Cichorioideae, Cirsium t., Brassicaceae, Filipendula, and Thalictrum. Meadow habitats were the source of such pollen as Potentilla type, Galium t., Apiaceae, and Bupleurum falcatum t. Steppe vegetation is testified by the presence of Artemisia, Poaceae, Chenopodiaceae, Helianthemum nummularium t., Asteraceae, Ranunculus acris t., and Centaurea. The presence of pollen of Ericaceae, Calluna vulgaris, Polygonum bistorta t., $P$. aviculare t., Polemonium, Valeriana, Plantago media and Ranunculus acris type should be related to assemblages of meadow-tundra vegetation. The Arctic-Alpine character of the plant habitats is emphasized by

Table 1

Pollen and spore taxa recovered from Stajnia Cave sediments

\begin{tabular}{|c|c|c|c|c|c|c|c|}
\hline $\begin{array}{l}\text { Trees and } \\
\text { shrubs }\end{array}$ & $\begin{array}{l}\text { Dwarf } \\
\text { shrubs }\end{array}$ & $\begin{array}{c}\text { Open, dry to } \\
\text { dry/fresh habitats }\end{array}$ & $\begin{array}{l}\text { Ecologically } \\
\text { undefined }\end{array}$ & $\begin{array}{c}\text { Open, fresh to wet } \\
\text { habitats }\end{array}$ & Aquatic plants & Pteridophyta & Bryophyta \\
\hline Acer & $\begin{array}{l}\text { Betula } \\
\text { nana t. }\end{array}$ & Artemisia & Apiaceae & $\begin{array}{c}\text { Armeria } \\
\text { maritima t. A }\end{array}$ & Nymphaea alba t. & Botrychium & Sphagnum \\
\hline Alnus & $\begin{array}{c}\text { Calluna } \\
\text { vulgaris }\end{array}$ & Astert. & Anthemis t. & Cirsium t. & $\begin{array}{c}\text { Typhal } \\
\text { Sparganium }\end{array}$ & $\begin{array}{l}\text { Botrychium } \\
\text { lunaria cf }\end{array}$ & \\
\hline Betula & Ericaceae & $\begin{array}{l}\text { Bupleurum } \\
\text { falcatum t. }\end{array}$ & Asteraceae & Dianthus t. & & B. simplex & \\
\hline Corylus & & Campanulaceae & Brassicaceae & Epilobium & & $\begin{array}{l}\text { Diphasiastrum } \\
\text { complanatum }\end{array}$ & \\
\hline Fraxinus & & Centaurea & Caryophyllaceae & Filipendula & & $\begin{array}{l}\text { Filicales } \\
\text { monolete }\end{array}$ & \\
\hline Juniperus & & C. jacea t. & Cerastium t. & & & $\begin{array}{l}\text { Huperzia } \\
\text { selago }\end{array}$ & \\
\hline Larix & & C. cyanus & Chenopodiaceae & Gentiana & & $\begin{array}{l}\text { Lycopodium } \\
\text { annotinum }\end{array}$ & \\
\hline Picea & & C. nigra t. & Cichorioideae & Lychnis t. & & L. clavatum & \\
\hline Pinus & & Helianthemum & $\begin{array}{l}\text { Cichorium } \\
\text { intibus t. }\end{array}$ & Mentha t. & & $\begin{array}{c}\text { Selaginella } \\
\text { selaginoides }\end{array}$ & \\
\hline P. cembra t. & & H. canum t. & Cyperaceae & Pastinaca sativa t. & & S. sibirica & \\
\hline Quercus & & H. nummularium t. & Dipsacaceae & Polemonium & & & \\
\hline Salix & & Saussurea t. & Galium t. & Polygonum & & & \\
\hline Tilia cordata t. & & $\begin{array}{l}\text { Scleranthus } \\
\text { annuus }\end{array}$ & Geranium & $P$. aviculare t. & & & \\
\hline \multirow[t]{13}{*}{ Ulmus } & & Vicia t. & Lactuca sativa t. & P. bistorta t. & & & \\
\hline & & & Lamiaceae & Rumex acetosa t. & & & \\
\hline & & & Plantago & Sagina t. & & & \\
\hline & & & P. media & $\begin{array}{c}\text { Sanguisorba } \\
\text { officinalis }\end{array}$ & & & \\
\hline & & & P. intermedia & Saxifraga & & & \\
\hline & & & Potentilla t. & S. granulata t. & & & \\
\hline & & & Ranunculus t. & S. hirculus t. & & & \\
\hline & & & $R$. acris t. & S. hirsuta t. & & & \\
\hline & & & Silene t. & S. oppositifolia t. & & & \\
\hline & & & Stachys & Succisa pratensis t. & & & \\
\hline & & & & Thalictrum & & & \\
\hline & & & & Urtica & & & \\
\hline & & & & Valeriana & & & \\
\hline
\end{tabular}


Saxifraga hirculus type, S. oppositifolia type, S. stellaris type, Polygonum bistora type pollen, and Selaginella selaginoides spores.

Levels I and III are characterized by the abundance of Pinus and Betula pollen with values reaching $20 \%$, whereas in level III, Picea and thermophilic trees as Tilia and Quercus pollen appear. However, the presence of oak and linden pollen and partly of Pinus may be related to far distance transport in open landscapes. Nevertheless, the presence of pine in the neighbourhood of the cave was confirmed by the presence of charcoals derived from the burning of pine wood (Kubiak-Martens and Kooistra, 2013).

FAUNA

The faunal assemblage from the Stajna Cave consists of $>13,500$ bones and bone fragments of large mammals and birds as well as $>8,000$ of small mammals and other smaller vertebrates (amphibians, reptiles). Mammal remains (>60 species) were present in all layers. In this paper we present only preliminary results of studies of assemblages from the Stajnia Cave for environmental reconstruction. A comprehensive analysis of fauna and taphonomic studies will be subject of a separate paper. Mammals are represented by insectivorous species like shrews (Sorex) (Soricomorpha), bats (Chiroptera), hares (Lepus) and pikas (Ochotona) representing lagomorphs (Lagomorpha), rodents (Rodentia), carnivorous mammals (Carnivora), odd-toed (Perissodactyla) and even-toed (Artiodactyla) ungulates and proboscideans (Mammuthus). The mammal remains belong to the so-called non-analogue or disharmonious associations. The assemblages consist of a mixture of boreal, steppe and woodland species. Remains of small mammals dominate in all layers. Species characteristic of well-drained or wet tundra areas are represented by the collared lemming (Dicrostonyx gulielmi), Norway lemming (Lemmus lemmus), and narrow-skulled vole (Microtus gregalis) in all layers (B-G). They contribute to $\sim 50$ and $70 \%$ of all remains of small mammals in all layers. Reindeer (Rangifer tarandus) is common in all layers among the large mammals. Remains of woolly mammoth (Mammuthus primigenius) were found, e.g., in layers D1, C18, D2b, and C19, of woolly rhinoceros (Coelodonta antiquitatis) in layers D1 and C18, and of arctic fox (Alopex lagopus) in layers C7 and D1. Willow ptarmigan (Lagopus lagopus) is the most common among birds. Remains of species of steppe or other dry-open habitats represent $\sim 1-3 \%$ frequency in all layers, except layer E (E1-E2) - 6-12\%, among the small mammal assemblage. Vole (Microtus arvalis) occurs in layers F, E, D (D3-D1) and C (C18); hamster (Cricetus cricetus) in layers $C$ (C18) and D (D1-D3); steppe lemming (Lagurus lagurus) in layer D (D3-D1). Steppe pika (Ochotona pusilla), a lagomorph species, is present in all layers. Large mammals are represented by the steppe wisent (Bison priscus) and horse (Equus ferus) in layer C (C18), and by the saiga antelope (Saiga tatarica) found only in layer B (earlier C2). Remains of species of diverse biotopes (tundra, taiga and forest-steppe) are the most numerous group among the remains of mammals found in the cave. Many of them are associated with moist and damp habitats (marshes, lakes and streams). The root vole (Microtus oeconomus) and European water vole (Arvicola amphibius) are common among small mammals. Wolf (Canis lupus), fox (Vulpes vulpes), cave bear (Ursus spelaeus s.l.), stoat (Mustela erminea) and weasel (Mustela nivalis) are the most common carnivore species in all layers among large and smaller carnivores. Remains of species inhabiting all kinds of woodlands were found in all layers. Bank vole (Clethrionomys glareolus) is the most common among small mammals with a frequency approximately between 2 and 14\%. Red deer (Cervus elaphus) was rarely found in some layers.

\section{OXYGEN ISOTOPE COMPOSITION}

A pilot study of oxygen isotope composition $\left(\delta^{18} \mathrm{O}\right)$ on bioapatite from the innermost enamel layer of reindeer's (Rangifer tarandus) tooth remains from the Stajnia Cave produced promising results. Most of teeth were sampled from sedimentary layers numbered as C19-D1 - E1-H. If their primary position was correctly preserved they represent different phases of of Vistulian (Weichselian).

One of several sequential $\delta^{18} \mathrm{O}$ profiles analysed in this study is presented on Figure 8, and a few representative are summarized in Table 2. Each one provides precise in situ analysis along the incremental enamel layer with a spatial resolution of a few microns, which reflects a temporal resolution of less than one month in a multi-year record. Enamel growth rates, however, are not completely constant and are known to vary also among modern species.

Approximately 50 to 120 analytical spots were placed within innermost matured bioapatite (enamel layer) adjacent to the enamel-dentine junction, according to chronology of growing from the incisal (older) to apical (newer) enamel. The distance between each spot varies from $0.13 \mathrm{~mm}$ to $0.15 \mathrm{~mm}$. Typically, the sequential spot profile of $\delta^{18} \mathrm{O}$ covered $>80-95 \%$ of length from the preserved enamel layer, that varies between 7.6 and $16.2 \mathrm{~mm}$. The pattern of intra-tooth $\delta^{18} \mathrm{O}$ variation broadly corresponds to an annual cycle observed in precipitation with the highest $\delta^{18} \mathrm{O}$ during the summer months and the lowest during the winter.

In general, oxygen isotope composition reflects a regular seasonal fluctuation in the $\delta^{18} \mathrm{O}$ (seasonality) or climate anomalies or migration symptoms (Britton et al., 2009; Aubert et al., 2012; Blumenthal et al., 2014; Krzemińska and Czupyt, 2015). In case of reindeer dental remains the annual intra-tooth fluctuation of $\delta^{18}$ OVSMOW values usually do not exceed $2.0 \%$, but most of examined bioapatite fragments have recorded one or two single higher changea of $\delta^{18} \mathrm{O}$, which could be deduced as seasonal reindeer migrations (Fig. 8B). In consequence, the total amplitude is much more higher, reflecting a complete change of environmental conditions in terms of oxygen composition of local water and temperature, where lower $\delta^{18} \mathrm{O}$ values reflect relatively colder climate conditions.

The average $\delta^{18} \mathrm{O}$ values (Table 2) represent an approximate and generalized oxygen composition. A much more detailed record of successive environmental input during the period of enamel formation is available based on the profile along the incremental enamel layer.

\section{ABSOLUTE DATING}

Dating of bones and sediments was made in the framework of archaeological investigations by $M$. Urbanowski from Szczecin University (Urbanowski et al., 2010). The first bone dating was made at the Laboratory in Poznan using the $\mathrm{C}^{14}$ AMS method (Table 3). The dated object was a tooth of a cave bear from layer D1; a date of $>49,000$ years BP was obtained (Poz-28892). The same method was used to date maxilla of a 

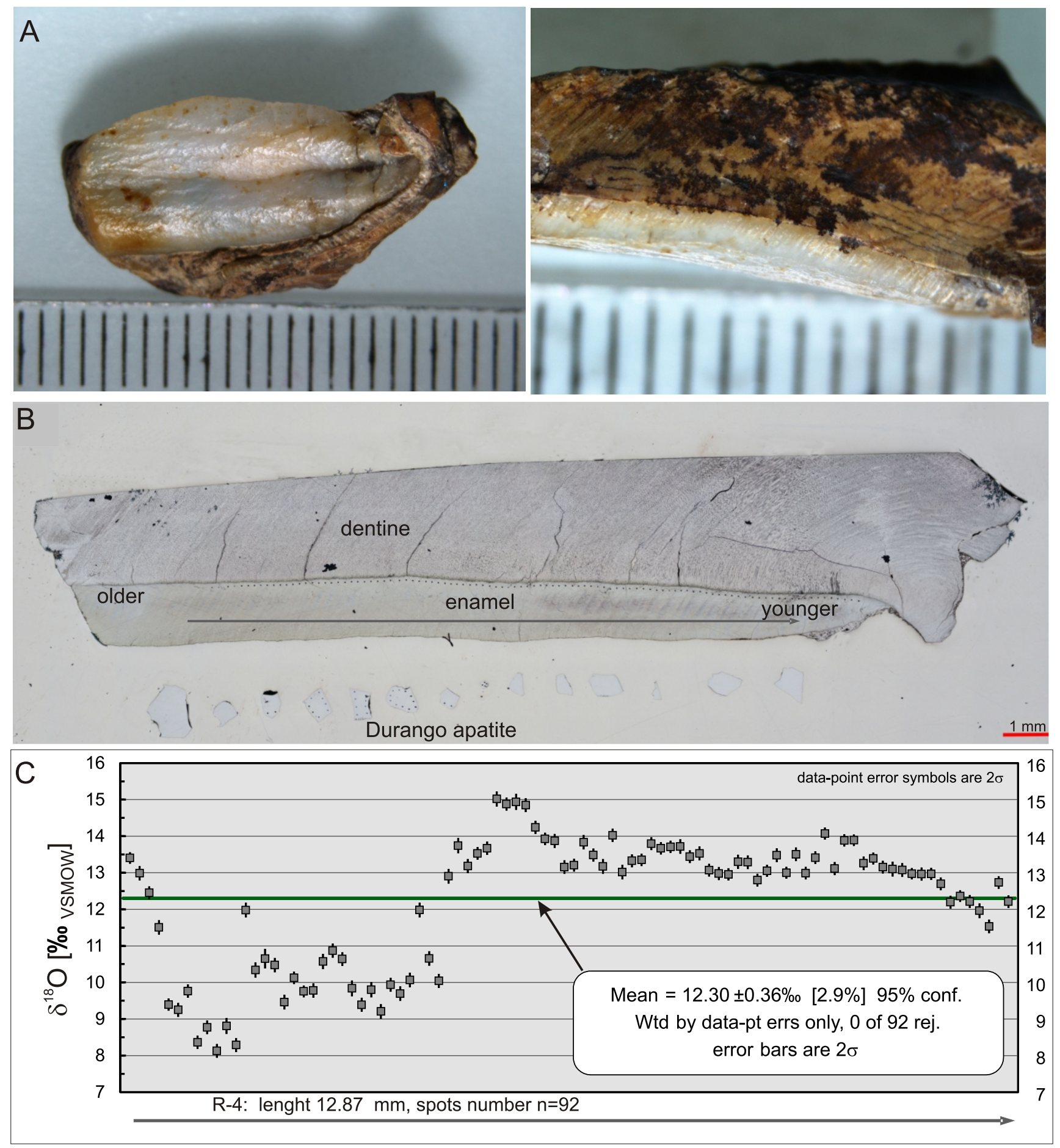

Fig. 8. Reindeer tooth oxygen isotope investigations

A - photographs showing state of preservation of tooth remains sampled from sedimentary layer E, a lingual side, sample R-4; ruler as a scale bar with $1 \mathrm{~mm}$, and natural section of tooth R-4 with exposed dentine/enamel junction; B - sample R4 versus reference material layout in epoxy resin; note tooth morphology and enamel and dentine enamel junction line and of spots after oxygen isotope measurements: images made in conventional microscope reflected light; $\mathbf{C}$ - sequential profile of the oxygen isotope composition from the innermost enamel layer of R4 tooth; oxygen isotope ratios $\delta^{18} \mathrm{O}$ are reported related to the Vienna Standard Mean Ocean Water (VSMOW)

saiga from layer $\mathrm{B}$; an age of $13,500 \pm 60 \mathrm{BP}$ was obtained (Poz-28891) (Nadachowski et al., 2016). $C^{14}$ dating of a fragment of a woolly mammoth tusk from layer D1 was made at the Oxford laboratory in England; a date of 44,600 years BP was obtained (OxA-24944).
Two U/Th datings (Laboratory for Isotope Dating and Environmental Research, Institute of Geological Sciences, Polish Academy of Sciences, Warsaw) were made on bone fragments (mammoth teeth) from layer D2b; the obtained date was 52,900 years BP (W1400; W1417). Three OSL datings were made at 
A summary of oxygen-isotope composition results and basic parameters of enamel layers of selected reindeer's teeth from the Stajnia Cave archeological site

\begin{tabular}{|l|c|c|c|c|c|c|c|}
\hline $\begin{array}{c}\text { Layer } \\
\text { no. }\end{array}$ & $\begin{array}{c}\text { Sample } \\
\text { ID }\end{array}$ & $\begin{array}{c}\text { Spots } \\
\text { number }\end{array}$ & $\begin{array}{c}\text { Profile } \\
\text { lenght } \\
{[\mathrm{mm}]}\end{array}$ & $\begin{array}{c}\delta^{18} \mathrm{O} \\
\text { VSMOW [\%o] } \\
\text { Min. value }\end{array}$ & $\begin{array}{c}\delta^{18} \mathrm{O} \\
\text { VSMOW [\%] } \\
\text { Max. value }\end{array}$ & $\begin{array}{c}\text { Range } \\
\text { of max. variations } \\
{[\%]}\end{array}$ & $\begin{array}{c}\text { Average } \\
\text { VSMOW [\%o] }\end{array}$ \\
\hline B7 & $\mathrm{R} 8 \mathrm{~F}$ & $\mathrm{n}=50$ & 5.75 & $2.91 \pm 0.31$ & $13.43 \pm 0.16$ & 10.52 & $8.76 \pm 0.40$ \\
\hline $\mathrm{C} 19$ & $\mathrm{R} 16$ & $\mathrm{n}=121$ & 13.28 & $9.10 \pm 0.09$ & $19.26 \pm 0.09$ & 10.16 & $14.22 \pm 0.18$ \\
\hline $\mathrm{D} 1$ & $\mathrm{R} 11$ & $\mathrm{n}=61$ & 9.89 & $9.56 \pm 0.09$ & $13.51 \pm 0.10$ & 3.95 & $11.18 \pm 0.13$ \\
\hline $\mathrm{D} 1$ & $\mathrm{R} 11$ & $\mathrm{n}=57$ & 9.20 & $9.61 \pm 0.08$ & $12.89 \pm 0.09$ & 3.28 & $11.18 \pm 0.13$ \\
\hline $\mathrm{E} 1$ & $\mathrm{R} 4$ & $\mathrm{n}=91$ & 12.87 & $8.13 \pm 0.11$ & $15.02 \pm 0.10$ & 6.89 & $12.21 \pm 0.19$ \\
\hline $\mathrm{H}$ & $\mathrm{R} 20$ & $\mathrm{n}=99$ & 11.86 & $4.78 \pm 0.10$ & $15.75 \pm 0.12$ & 10.52 & $9.86 \pm 0.22$ \\
\hline
\end{tabular}

Results of absolute dating

\begin{tabular}{|c|c|c|c|c|c|c|c|c|}
\hline No. & Method & Laboratory & Reference & $\begin{array}{c}\text { Results } \\
\text { in ka BP }\end{array}$ & Uncertainty & Processed results & Unit & Description \\
\hline 1 & U-Th & Warszawa & W1400 & 52 & $+19-17$ & 52.9 & D2b & $\begin{array}{c}\text { Mammuthus } \\
\text { primigenius tooth }\end{array}$ \\
\hline 2 & U-Th & Warszawa & W1417 & 52 & $+5-2$ & 52.9 & D2b & $\begin{array}{c}\text { Mammuthus } \\
\text { primigenius tooth }\end{array}$ \\
\hline 3 & AMS C $^{14}$ & Poznań & Poz-28892 & $>49$ & open date & calibration not possible & D1 & Ursus spelaeus tooth \\
\hline 4 & OSL $^{14}$ & Gliwice & GdTL-1127 & 45.9 & & & D1 & loam \\
\hline 5 & AMS C $^{14}$ & Oxford & OxA-24944 & 44.6 & 2.1 & $\begin{array}{c}\text { Cal Pal: 46,388 } \pm 2567, \\
\text { OxCal: over 46.4 ka BC cal }\end{array}$ & D1 & $\begin{array}{c}\text { Mammuthus } \\
\text { primigenius tusk }\end{array}$ \\
\hline 6 & AMS C & Poznań & Poz-28891 & 13.5 & 0.06 & $14,506 \pm 407$ cal BC (Cal Pal) & B & Saiga tatarica maxilla \\
\hline 7 & OSL & Gliwice & GdTL-1126 & 8.95 & & & B & loam \\
\hline
\end{tabular}

the Institute of Physics, Silesian University of Technology in Gliwice. Two OSL dates came from silty-sandy sediments infilling a fracture in the Stajnia Cave. The result for the upper sample is 8,950 years BP (GdTL-1126), and for the lower sample 45,900 years BP (GdTL-1127). The result for the second sample may be correlated with the age of the sediments from layer $D 1$. A series of $C^{14}$ dates were made for layer $D$ sediments at the Max Planck Institute for Evolutionary Anthropology, Leipzig, Germany. Their results are correlated with the Middle Plenivistulian (Middle Pleniglacial) and will be presented in a separate publication.

\section{PALAEOENVIRONMENTAL CONDITIONS DURING THE ACCUMULATION OF THE LAYERS, AND DISCUSSION}

\section{GEOLOGY}

The differences in the physical and chemical properties of the sediments composing the particular layers are not significant. Layer G (Table 4) was accumulated probably in warmer and more humid conditions than the remaining layers. This is reflected in the higher content of the clay fraction, lower content of the silt fraction, and small amounts of large rubble. Shining quartz grains dominate in this layer. There is a prevalence of opaque minerals, and a smaller amount of garnet among the transparent minerals, as well as a larger content of manganese among the trace elements. Layer $\mathrm{F}$ was probably accumulated in slightly colder conditions, because most features of the sedi- ments indicate average physical-chemical properties of the sediments of the remaining layers. Like in the other layers, there is a prevalence of quartz with aeolian features, correlated with a cold climate. Features pointing to warmer conditions include the prevalence of opaque minerals, a smaller content of garnet, larger content of manganese, very low content of titanium, and the presence of manganese-phosphorus coatings on the rubble surface. Features of the sediments in layer E2 indicate both warmer and colder environments. The high content of large rubble and the aeolian character of quartz sediments point to a colder environment. Warmer and more humid settings are indicated by manganese-phosphate coatings on the rubble, a lower content of garnet, and the prevalence of opaque minerals. Other features of the sediments are similar to those of the remaining layers. There is a possibility that the rubble developed in a colder period, while the cave loams infilling the space between them - in a warmer period. A similar situation took place during the accumulation of layer E1, which is dominated by limestone rubble characteristic of cold climate and by quartz grains with aeolian reworking. A higher content of smoothened rubble, manganese-phosphate coatings on the rubble surface, lower amounts of garnet, and higher contents of opaque minerals point to more favourable, slightly warmer conditions during the accumulation of sediments of this layer. Archaeological layers D3, D2, D2b, and D1 were accumulated in variable conditions, rather with the prevalence, predominantly of warmer conditions over colder ones. Warmer conditions are indicated by the increased content of clay fraction (layer D3), low content of silt fraction (D1, D2b), admixture of smoothened rubble and rubble with manganese-phosphate coatings on the surface (D1, $\mathrm{D} 2 \mathrm{~b})$, prevalence of opaque minerals, lower content of garnet, 
Layer description and age correlation

\begin{tabular}{|c|c|c|c|}
\hline Layers & Sediments & Absolute dating in ka BP & MIS \\
\hline A & grey-black humus with limestone rubble & & 1 \\
\hline & \multirow[b]{2}{*}{ yellow sandy cave loam with rubble } & OSL 8.95 (GdTL-1126) & \multirow{6}{*}{2} \\
\hline B6 & & AMS $C^{14} 13.5$ (Poz-28891) & \\
\hline B7 & yellow silty-sandy cave loam with rubble & & \\
\hline $\mathrm{C} 6$ & yellow sandy cave loam with rubble & & \\
\hline C7 & brown-yellow cave loam & & \\
\hline C18 & light grey silty-sandy cave loam with limestone rubble & & \\
\hline C19 & grey cave loam with red streaks and limestone rubble & & \multirow{6}{*}{3} \\
\hline \multirow[t]{2}{*}{ D1 } & light brown cave loam with rubble, main archaeological horizon & $\begin{array}{c}\text { AMS C }^{14}>49(\mathrm{OxA}-24944) \\
\text { OSL } 45.9(\text { GdTL-1127) }\end{array}$ & \\
\hline & & AMS C ${ }^{14}>49($ Poz-28892) & \\
\hline $\mathrm{D} 2 \mathrm{~b}$ & light brown sandy-clayey-silty cave loam with rubble, archaeological horizon & $\begin{array}{l}\text { U-Th } 52.9(\mathrm{~W} 1417) \\
\text { U-Th } 52.9(\mathrm{~W} 1400)\end{array}$ & \\
\hline D2 & light brown cave loam with rubble, archaeological horizon & & \\
\hline D3 & dark brown sandy-silty-clayey cave loam with rubble, archaeological horizon & & \\
\hline E1 & grey cave loam with abundant limestone rubble & & 4 \\
\hline E2 & brown grey, in places black, silty-clayey-sandy loam with rubble & & \multirow{4}{*}{5} \\
\hline $\mathrm{F}$ & light grey, in places brown, sandy cave loam with low admixture of limestone rubble & & \\
\hline G & orange-brown sandy cave loam with low admixture of limestone rubble & & \\
\hline $\mathrm{H}$ & orange cave loam & & \\
\hline
\end{tabular}

and slightly higher content of humus in the sediments (D1, D2). Features of sediments pointing to slightly colder climate include a higher content of large rubble (layer D1), aeolian reworking of quartz grains, prevalence of transparent minerals (D1, D2b), higher content of garnets (D1, D2b), and low content of phosphorus (D2). Layer C19 (Table 4) was accumulated probably in colder conditions. Values of most parameters of the sediments are within the average for particular layers, but there are no features indicating warmer conditions during the accumulation of sediments of this layer. The prevalence of transparent minerals, higher content of garnet, increased content of calcium carbonate, and high aeolization of quartz grains indicate colder accumulation conditions. Significantly colder and probably drier conditions took place during the accumulation of layers $\mathrm{C} 18$, $\mathrm{C} 7, \mathrm{~B} 7$ and B6. This is evidenced by the higher content of silt (B7, C18), lowest content of clay (B7, C18), higher content of large rubble (B6), dominance of sharp-edged rubble (C18), prevalence of transparent minerals $(\mathrm{C} 7, \mathrm{C} 6)$, higher content of garnet $(\mathrm{C} 6, \mathrm{~B} 6)$, lower content of phosphorus and manganese (C7, C6, B6), high values of titanium $(\mathrm{C} 7, \mathrm{C} 6, \mathrm{~B} 6)$, higher values of calcium carbonate (C7, C6, B6), and high aeolization of quartz grains. Only a few properties of the sediments in these layers point to warmer conditions. They include: low contribution of silt (B6), prevalence of opaque minerals (B7), and smaller amounts of garnet (C7).

\section{POLLEN}

Based on pollen data it can be concluded that dominant vegetation during the sedimentation of layers D2-D1, C19-C18 and C7-C6 points to an open landscape with assemblages of open habitats such as steppe-like, tundra and meadow-tundra with a patchwork character of vegetation depending on the humidity of the bedrock, soil type, slope angle and elevation. However, based on pollen data it can be assumed that, in contrast to the Early Vistulian (Behre, 1989), tundra assemblages dominated.
The pollen record indicates that the climate conditions in level II (layers D1 and C19-18) were severe and a subarctic climate probably prevailed. The low contribution of tree pollen indicates that the Stajnia Cave was at that time beyond the range or at the northern tree line. This may evidence that the mean temperature of the warmest month did not exceed $+12^{\circ} \mathrm{C}$ (Wasylikowa, 1964). Influence of continental climate was significant as evidenced by the presence of pollen of Polemonium caereuleum type (Zarzycki et al., 2002). It was probably warmer in level I and especially in level III due to the higher proportion of birch and pine pollen and the appearance of spruce, linden and oak. Loosely distributed pine-birch groupings with spruce were most probably formed during this level. Oak and linden pollen might have likely been derived from long distant transport; however, it may indicate the close presence of these trees in forest communities to the south of the Carpathians. In level III, the abundance of Sphagnum spores should be linked with higher rainfall rates and expansion of peatlands.

\section{FAUNA}

Full reconstruction of past ecosystems is impossible because many species making up the fossil assemblages are not preserved in the fossil record as a result of taphonomic bias. For instance, the number of forest species in the small mammal cave assemblages is probably underestimated. However, taking into account taphonomic impact on the fauna, it is possible to correlate the ecological and climatic change with changes in the taxonomic composition of the vertebrate fauna. Faunal studies indicate that past ecosystems in this area were a mosaic of habitats, with open (tundra, steppe) and forested areas, swamps, water streams and lakes as well as rocky areas. Tundra conditions dominated. Based on the analysis of the faunal remains, it can be stated that the climate was slightly more humid and warmer during the accumulation of layers $G$ and $F$, and slightly colder and drier for layers E, D, C and B. 


\section{OXYGEN ISOTOPES}

Mammalian teeth incorporate all natural fluctuations of the oxygen isotope composition during time of enamel mineralisation. The ${ }^{18} \mathrm{O} /{ }^{16} \mathrm{O}$ ratio of enamel bioapatite is controlled by ingested water and may be influenced by several external factors, such as aridity, precipitation, relative humidity, temperature, latitude, elevation, diets and metabolism (Fricke and O'Neil, 1996; Fricke et al., 1998). For large-sized mammals, body temperatures are kept constant and $\delta^{18} \mathrm{O}$ enamel is not affected by metabolic processes, but rather by meteoric water. The variations in the oxygen isotope composition of meteoric water reflect seasonal climatic changes, e.g. warm/cold months at high and mid latitudes (e.g., Różański et al., 1993). Hence, the oxygen isotopic composition of enamel, especially for herbivores, may record $\delta^{18} \mathrm{O}$ of meteoric water and thus reflect the climatic and palaeoenvironmental characteristics of the period of enamel mineralisation (Blaise and Balasse, 2011).

Mean values of $\delta^{18} \mathrm{O}$ enamel from adjacent layers numbered as C19-D1 - E1-H are different (Table 2). The high value of $14.22 \pm 018 \%$ of layer $C$ document relatively warmer conditions than the values of $11.18 \pm 013 \%$ from layer $D$, which is similar to the $\delta^{18} \mathrm{O}$ enamel composition of present-day reindeers from the Spitzbergen Islands-Arctic Sea (Longinelli et al., 2003) measured by conventional methods. In situ intra-tooth oxygen isotope analysis allows identification of summer and winter ranges of fluctuations and detecting expected migratory behaviour. The degree of intra-tooth $\delta^{18} \mathrm{O}$ variation may also in- dependently indicate truly migratory behaviour as opposed to smaller-scale seasonality of interglacial period (Fig. 8).

For comparison, the stable oxygen isotope composition of animal teeth of Pleistocene animals in the open archaeological site of Haller Street in Wrockaw from the AB complex (OIS5) yielded a mean $\delta^{18} \mathrm{Op}$ value of tooth phosphates of 13.8 $\pm 0.80 \%$ that corresponds to a mean annual temperature of 6.8 $\pm 1.5^{\circ} \mathrm{C}$ for the Middle Plenivistulian (Interplenivistulian) (Skrzypek et al., 2011).

\section{SUMMARY}

The dataset obtained from multi-proxy analyses have indicated differences in the development of sediments in particular layers, and their physical and chemical features. The differences are insignificant and correspond to climate oscillations during the accumulation of the layers. Generally, all sediments were accumulated in a relatively cold climate. The warmest and simultaneously most humid climate conditions took place during the accumulation of layer $\mathrm{G}$, and its age may be correlated with MIS 5c, which corresponds to the Brørup Interstadial (Fig. 9). During the accumulation of layer $F$, the climate conditions were also relatively warm, but slightly cooler than for layer $G$. The age of this layer may be correlated with MIS $5 \mathrm{~b}$, which would correspond to the Redestall Stadial or the end of the Brørup Interstadial.

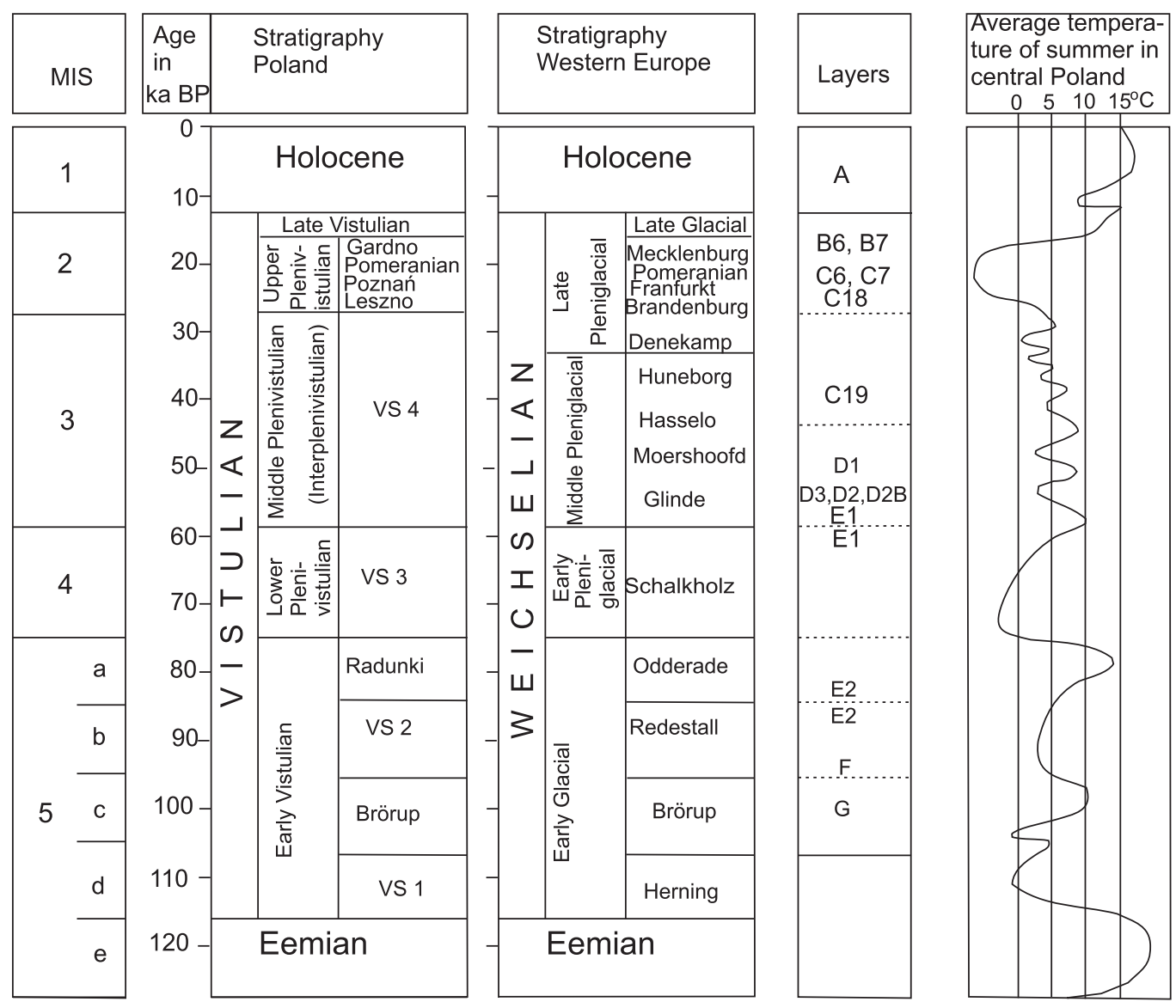

Fig. 9. The Stajnia Cave layers in relation to the stratigraphic subdivision of the Vistulian/Weichselian in Poland and Western Europe after Behre (1989), Mojski (2005), Cyrek and Madeyska (2011) and Marks et al. (2016) 
The mean temperature in southwestern Poland could have reached $6.8^{\circ} \mathrm{C}$ (Skrzypek et al., 2011). Layers E2 and E1 were formed in two stages, which is confirmed by the analyses. The rubble layer E2 was accumulated probably in the Redestall Interstadial - MIS 5b (VS 2), and the infilling sediments - in the warmer Odderade (Rudunki) Interstadial MIS 5a (Fig. 9). A similar case is with layer E1, in which the rubble was formed during a relatively cool stadial interval (Schalkholz - MIS 4), and the sediments filling the spaces between the rubble were formed in a warmer interval of the Interplenivistulian - MIS 3, most probably during the Glinde Interstadial. Archaeological layers D3, D2, D2b and D1, related to the habitation of the cave by Neanderthals, were accumulated during the Interplenivistulian - MIS 3, which was generally characterized by warmer climate conditions, but with numerous warm and cold oscillations (Rassmusen, 2014). The temporal range of the Neanderthal habitation of the cave is within about $52,000-45,000$ years BP. Most recent data from ice cores in Greenland indicate that there were a number of warmer events in this interval, the so-called "DO events", during which the temperature reached even $16.5^{\circ} \mathrm{C}$ during the warmest month (Kindler et al., 2014). Based on the results, layers D3 and D2 were formed in a warmer interval of the Interplenivistulian, the Glinde Interstadial (at 52,900 BP; Table 3). Most probably, layer D2b was accumulated during a colder episode of this interstadial. During the accumulation of layer D1, the climate was slightly colder and drier. This may be indicated by the distribution of open vegetation. The age of this bed may be related to the end of the Glinde Interstadial and the Hassello Stadial $(44,600$ years BP, MIS 3; Fig. 9). The results of pollen analyses in layers D2-D1, C19-C18 and C7-C6 do not reveal any differences in the climate conditions during the accumulation of these layers. Based on pollen data it can be concluded that the climate was harsh, and the mean temperature of the warmest month did not exceed $12^{\circ} \mathrm{C}$. Isotope analyses of reindeer teeth in layers D2-D1 also suggest cold climate conditions, which were close to those prevailing at present on Spitsbergen. Layer C19 was accumulated in a slightly colder climate than the complex of layers $D$, and its age should be linked with the end of the Interplenivistulian (MIS 3) and correlated probably with the Huneborg Stadial. Results of isotope analysis of reindeer teeth point to slightly warmer climate conditions during the accumulation of layer C19 than during the accumulation of layers D1-D2. Such results indicate climate oscillations. Teeth in layer C19 may represent a warmer climate pulse during the accumulation of this layer. Layer $\mathrm{C} 18$ was accumulated in a much colder climate than the layers described above, and is correlated with the beginning of MIS 2 - the Leszno (Brandenburg) Phase (Fig. 9). The coldest and probably driest conditions prevailed during the accumulation of layers C7, C6 and B7. This conclusion is confirmed by the results of geological analyses, although pollen data point to a slight warming in relation to layers $C 18$ and C19. The age of these sediments should be linked with the Leszno-Poznań-Pomeranian-Gardno (Brandenburg-Frankfurt-Pomeranian-Mecklenburg) Phase (Fig. 9). Possibly part of layer B6 was accumulated already in the Late Vistulian (Late Glacial). Such supposition is confirmed by $\mathrm{C}^{14}$ dates. Layer A was accumulated in a temperately warm climate of the Holocene (MIS 1). A few fragments of the bones of forest animal species, as well as pollen and tree macroremains, recovered from of the Stajnia Cave, may point to intervals of short-termed climate warming. The intervals were, however, too short to affect the type of sediment of the floral-faunal communities.

\section{CONCLUSIONS}

The cave loams (15 lithostratigraphic layers) were accumulated in the Stajnia Cave from the Early Vistulian (Early Glacial) to the Upper Plenivistulian (Late Pleniglacial) and Holocene. Archaeological excavations have not reached the bottom of the cave and the thickness of sediments filling the cave may be a few metres. Archaeological relics related to Neanderthals have been discovered in the complex of layer $D$ with an absolute age of about 52,000-45,000 years BP and correlated with MIS 3 the Middle Plenivistulian (Middle Pleniglacial). Geological, palaeozoological, palaeobotanic and isotope analyses suggest that conditions characteristic of tundra areas with a typical vegetation and fauna prevailed during the habitation of Neanderthals in the vicinity of the Stajnia Cave. Temperature of the warmest month did not exceed $12^{\circ} \mathrm{C}$. Palaeoecological data presented in this study can be useful in further analyses concerning Neanderthal exploitation strategies of Late Pleistocene environmental resources including information about Neanderthal diet. Faunal and pollen analyses lead to a conclusion that the ecosystems had a mosaic distribution, characteristic of the Vistulian (Weichselian). The record of the multiproxy analysis in the sediments filling the cave does not reflect all palaeoclimate oscillations of the Vistulian (Weichselian). Loams in the cave probably do not represent a full succession of the Vistulian and are disturbed by human activity, starting with the Middle Palaeolithic until present. However, the results presented in the paper have allowed reconstructing the local palaeoenvironmental and climate conditions during the Vistulian (Weichselian) in the vicinity of the Stajnia Cave.

Acknowledgments. Geological investigations in the Stajnia Cave have been conducted in the framework of the Polish Geological Institute - National Research Institute grant no. 61.3608.1302.00.0. The research was supported by the Department of Archaeology of Institute of History and International Relations from Szczecin University, Department of Paleozoology of Institute of Environmental Biology from University of Wrocław, and Department of Human Biology from University of Wrocław. Authors are very grateful to researchers who make analyses mentioned below. Geophysical investigation was performed under the supervision of P. Zientara from the Polish Geological Institute - National Research Institute (PGI-NRI). Analysis of the grain-size composition was made using the laser diffraction method by W. Wolski at PGI-NRI. J Mirosław-Grabowska from the Institute of Geological Sciences, Polish Academy of Sciences in Warsaw, analysed the calcium carbonate content, partly limestone rubble morphology, humus content, and mineral precipitation on limestone. The analysis of frosting of quartz grains was conducted by M. Pindara at PGI-NRI. Geochemical analyses of XRD (X-ray diffraction) and $\mathrm{XRF}$ (X-ray fluorescence) were conducted at PGI-NRI by M. Bojakowska (PGI-NRI) and interpreted by K. Rywocka-Kenig (PGI-NRI). Analyses of the content of main and trace elements (ppm) were carried out by J. Kucharzyk (PGI-NRI). We are grateful to T. Madeyska, M. Grove and W. Granoszewski for helpful comments. 


\section{REFERENCES}

Aubert, M., Williams, I.S., Boljkovac, K., Moffat, I., Moncel, M.-H., Dufour, E., Grün, R., 2012. In situ oxygen isotope micro-analysis of faunal material and human teeth using a SHRIM P II: a new tool for palaeo-ecology and archaeology. Journal of Archaeological Science, 39: 3184-3194.

Baca, M., Popović, D., Stefaniak, K., Marciszak, A., Urbanowski, M., Nadachowski, A., Mackiewicz, P., 2016. Retreat and extinction of the Late Pleistocene cave bear (Ursus spelaeus sensu lato). Science of Nature, 103: 92.

Barczuk, A., Nejbert, K., 2007. Analiza minerałów nieprzeźroczystych w badaniach osadów okruchowych (in Polish). In: Badania cech tekstualnych osadów czwartorzędowych i wybrane metody oznaczania ich wieku (eds. E. Mycielska-Dowgiałło and J. Rutkowski): 205-228. Wydawnictwo SWPR, Warszawa.

Behre, K.E., 1989. Biostratigraphy of the last glacial period in Europe. Quaternary Science Reviews, 8: 25-44.

Blaise, E., Balasse, M., 2011. Seasonality and season of birth of modern and late Neolithic sheep from south-eastern France using tooth enamel $\delta^{18} \mathrm{O}$ analysis. Journal of Archaeological Science, 38: 3085-3093.

Blumenthal, S.A., Cerling, T.E., Chritz, K.L., Bromage, T.G., Kozdon, R., Valley, J.W., 2014. Stable isotope time-serie in mammalian teeth: in situ $\delta^{18} \mathrm{O}$ from innermost enamel layer. Geochimica et Cosmochimica Acta, 124: 223-236.

Britton, K., Grimes, V., Dau, J., Richards, M.P., 2009. Reconstructing faunal migration using intra-tooth sampling and strontium and oxygen isotope analyses a case study of modern caribou (Rangifer Tarandus granti). Journal of Archaeological Science, 36: 1163-1172.

Carrión, J.S., 1995. A palaeoenvironmental study in semi-arid Southeastern Spain: the palynological and sedimentological sequence at Perneras Cave (Lorca, Murcia). Journal of Archaeological Science, 22: 355-367.

Chmielewski, W., 1969. Ensambles Micoquo-Prondnikiens en Europe Central. Geographia Polonica, 17: 371-386.

Chmielewski, W., 1970. Wyniki badań w Schronisku Wylotnym w Ojcowie (in Polish). Sprawozdania Archeologiczne, 22: 47-55.

Chmielewski, W., 1975. Paleolit środkowy i górny (in Polish). In: Prahistoria ziem polskich (ed. W. Chmielewski). Zakład Narodowy im. Ossolińskich, Warszawa.

Chmielewski, W., Kowalaski, K., Madeyska-Niklewska, T., Sych, L., 1967. Studies on the deposits of Koziarnia Cave of Sąspów in the Olkusz district. Folia Quaternaria, 26: 1-69.

Combourieu Nebout, N., Peyron, O., Dormoy, I., Desprat, S., Beaudouin, C., Kotthoff, U., Marret, F., 2009. Rapid climatic variability in the west Mediterranean during the last 25000 years from high resolution pollen data. Climate of the Past, 5: 503-521.

Cyrek, K., ed., 2002. Jaskinia Biśnik. Rekonstrukcja zasiedlenia jaskini na tle zmian środowiska przyrodniczego (in Polish). Wydawnictwa Uniwersytetu M. Kopernika, Toruń.

Cyrek, K., Madeyska, T., 2011. Stone Age in the Ojców Jura on the background of natural environment changes. Materiały 45 Sympozjum Speleologicznego, Ojców, 0-23.10.2010: 51-53.

Cyrek, K., Socha, P., Stefaniak, K., Madeyska, T., Mirosław-Grabowska, J., Sudoł, M., Czyżewski, Ł., 2010. Palaeolithic of Biśnik Cave (Southern Poland) within the environmental background. Quaternary International, 220: 5-30.

Cyrek, K., Sudoł, M., Czyżewski, Ł., Osipowicz, G., Grelowska, M., 2014. Middle Palaeolithic cultural levels from Middle and late Pleistocene sediments of Biśnik Cave, Poland. Quaternary International, 326-327: 20-63.

Dąbrowski, P., Nowaczewska, W., Stringer, C.B., Compton, T., Kruszyński, R., Nadachowski, A., Stefaniak, K., Urbanowski, M., 2013. The Neanderthal lower molar from Stajnia Cave, Poland. HOMO - Journal of Comparative Human Biology, 64: 89-103.

Dimbleby, G.W., 1985. The Palynology of Archaeological Sites. Academic Press, London.
El Zaatari, S., Grine, F.E., Ungar, P.S., Hublin, J-J., 2011. Ecogeographic variation in Neandertal dietary habits: evidence from occlusal microwear texture analysis. Journal of Human Evolution, 61: 411-424.

El Zaatari, S., Grine, F.E., Ungar, P.S., Hublin, J-J., 2016. Neandertal versus modern human dietary responses to climatic fluctuations. PLOS ONE, 11: e0153277.

Erdtman, G., 1960. The acetolysis method. A revised description. Svensk Botanisk Tidskrift, 54: 561-564.

Fricke, H.C., O'Neil, J.R., 1996. Inter- and intra-tooth variation in the oxygen isotope composition of mammalian tooth enamel phosphate: implications for palaeoclimatological and palaeobiological research. Palaeogeography, Palaeoclimatology, Palaeoecology, 126: 91-99.

Fricke, H.C., Clyde, W.C., O'Neil, J.R., 1998. Intra-tooth variations in $\delta^{18} \mathrm{O}\left(\mathrm{PO}_{4}\right)$ of mammalian tooth enamel as a record of seasonal variations in continental climates. Geochimica et Cosmochimica Acta, 62: 1839-1850.

Goździk, R., 1981. Les changements de processus éoliens dans la Pologne Centrale au cours du Vistulien (Würm). Recherches Géographiques á Strasbourg, 16-17: 115-120.

Gradziński, R., Kostecka, A., Radomski, A.M., Unrug, R., 1986. Zarys sedymentologii. Wyd. Geol., Warszawa.

Groner, U., 1985. Palynologie der Karsthohlensendimente im Holloch, Zentralschweiz. Gebo Druck AG., Zurich.

Heliasz, Z., Lewandowski, J., Liszkowski, J., Wielgomas, L., 2009. Szczegółowa Mapa Geologiczna Polski w skali 1:50 000, arkusz Żarki (in Polish). Państwowy Instytut Geologiczny, Warszawa.

Homsey, L.K., Capo, R.C., 2006. Integrating geochemistry and micromorphology to interpret feature use at Dust Cave, a Paleo-Indian through middle-archaic site in Northwest Alabama. Geoarcheology, 21: 237-269.

Ickert, R.B., Hiess, J., Williams, I.S., Holden, P., Ireland, T.R., Lanc, P., Schram, N., Foster, J.J., Clement, S.W., 2008. Determining high precision, in situ, oxygen isotope ratios with SHRIMP II: analyses of MPI-DING silicate-glass reference materials and zircon from contrasting granites. Chemical Geology, 257: 114-128.

Kindler, P.M., Guillevic, M., Baumgartner, M., Schwander, J., Landais, A., Leuenberger, M., 2014. Temperature reconstruction from 10 to $120 \mathrm{kyr} b 2 \mathrm{k}$ from the NGRIP ice core. Climate of the Past, 10: 887-902.

Kozłowski, S.K. ed., 2006. Wylotne and Zwierzyniec. Paleolithic sites in southern Poland. The Polish Academy of Arts and Sciences, Warsaw University, Warsaw.

Krajcarz, M.T., Madeyska, T., 2010. Application of the weathering parameters of bones to stratigraphical interpretation of the sediments from two caves (Deszczowa Cave and Nietoperzowa Cave, Kraków-Częstochowa Upland, Poland). Studia Quaternaria, 27: 43-54.

Krajcarz, M.T., Bosák, P., Šlechta, S., Pruner, P., Komar, M., Dresler, J., Madeyska, T., 2014. Sediments of Biśnik Cave (Poland): lithology and stratigraphy of the Middle Palaeolithic site. Quaternary International, 326-327: 6-19.

Krzemińska, E., Czupyt, Z.J., 2015. The $\delta^{18} \mathrm{O}$ record explored within a dental targets by SHRIMP IIe/MC. Mineralogical Magazine-Goldschmidt Conference Abstracts: 1701.

Krzemińska, E., Sołtysiak, A., Czupyt, Z.J., 2017. Reconstructing seasonality using $\delta^{18} \mathrm{O}$ in incremental layers of human enamel: a test of the analytical protocol developed for SHRIMP IIe/MC ion microprobe. Geological Quarterly, 61 (2): 370-383.

Kubiak-Martens, L., Kooistra, L., 2013. Plant remains from Stajnia Cave. In: Stajnia Cave (ed. M. Urbanowski): 112-130. Multidisciplinary research 2006-2010. Stone Age Research. Archaeological Department, Institute of History and International Relates, Szczecin University.

Leroi-Gourhan, A., 1997. Chauds et froides de 60000 a 15000 BP Bulletin de la Société Préhistorique Française, 94: 151-160. 
Lityńska-Zając, M., Wasylikowa, K., 2005. Guidebook to Archeobotanical Studies. Vademecum Geobotanicum, Sorus, Poznań.

Longinelli, A., lacumin, P., Davanzo, S., Nikolaev, V., 2003. Modern reindeer and mice: revised phosphate water isotope equations. Earth and Planetary Science Letters, 241: 491-498.

Madeyska-Niklewska, T., 1969. Upper Pleistocene deposits in cave of the Cracow Upland (in Polish with English summary). Acta Geologica Polonica, 19: 341-392.

Madeyska-Niklewska, T., 1971. Method used in researches on the Upper Pleistocene sediments in the Cracow Upland caves (in Polish with English summary). Światowid, 32: 5-25.

Madeyska, T., 1981. Le milieu naturel de l'homme du Paléolithique moyen et supérieur en Pologne à la lumière des recherches géologiques (in Polish with French summary). Studia Geologica Polonica, 69: 1-125.

Madeyska, T., 1982. The stratigraphy of Palaeolithic sites of the Cracow Upland. Acta Geologica Polonica, 32: 227-242.

Madeyska, T., 2009. Clastic cave sediments in the Częstochowa Upland. Studies of the Faculty of Earth Sciences University of Silesia, 56: 67-84.

Madeyska, T., Cyrek, K., 2002. Cave fillings - a chronicle of the past. An outline of the Younger Pleistocene cave sediments study in Poland. Acta Geologica Polonica, 52: 75-95.

Marks, L., Gałązka, D., Woronko, B., 2016. Climate, environment and stratigraphy of the last Pleistocene glacial stage in Poland. Quaternary International, 420: 259-271.

Mojski, J.E., 2005. Ziemie polskie w czwartorzędzie (in Polish). Zarys morfogenezy. Państwowy Instytut Geologiczny, Warszawa.

Marcinkowski, B., Mycielska-Dowgiałlo, E., 2013. Heavy-mineral analysis in Polish investigations of Quaternary deposits: review. Geologos, 19: 5-24.

Migaszewski, Z.M., Gałuszka, A., 2007. Podstawy geochemi środowiska (in Polish). Wydawnictwo Naukowo-Techniczne, Warszawa.

Mirosław-Grabowska, J., 2002. Litologia i stratygrafia osadów Jaskini Biśnik (in Polish). In: Jaskinia Biśnik. Rekonstrukcja zasiedlenia jaskini na tle zmian środowiska przyrodniczego (ed. K. Cyrek): 143-179. Wydawnictwa Uniwersytetu M. Kopernika, Toruń.

Mycielska-Dowgiałło, E., 2007. Metody badań cech strukturalnych osadów klastycznych i wartość interpretacyjna wyników. In: Badania cech teksturalnych osadów czwartorzedowych i wybrane metody oznaczania ich wieku (ed. E. Mycielska-Dowgiałło and J. Rutkowski): 95-180. Wydawnictwo SWPR, Warszawa.

Nadachowski, A., Żarski, Urbanowski, M., Wojtal, P., Miękina, B., Lipecki, G., Ochman, K., Krawczyk, M., Jakubowski, G., Tomek, T., 2009. Late Pleistocene environment of the Częstochowa Upland (Poland) reconstructed on the basis of faunistic evidence from archaeological cave sites. Institute of Systematics and Evolution of Animals, PAS, Kraków: 1-112.

Nadachowski, A., Lipecki, G., Ratajczak, U., Stefaniak, K. Wojtal, P., 2016. Dispersal events of the saiga antelope (Saiga tatarica) in Central Europe in response to the climatic fluctuations in MIS 2 and the early part of MIS 1 . Quaternary International, 245: 186-192.

Navarro, C., Carrión, J.S., Munuera, M., Prieto, A.R., 2001. Cave surface pollen and the palynological potential of karstic cave sediments in palaeoecology. Review of Palaeobotany and Palynology, 117: 245-265

Nowaczewska, W., Dabrowski, P., Stringer, C.B., Compton, T., Kruszyński, R., Nadachowski, A., Socha, P., Binkowski, M., Urbanowski, M., 2013. The tooth of a Neanderthal child from Stajnia Cave, Poland. Journal of Human Evolution, 64: 225-231.

Ossowski, G., 1885. Jaskinie okolic Ojcowa pod względem paleo-etnologicznym (in Polish). Pamiętniki Wydziału Matematyczno-Przyrodniczego Akademii Umiejętności w Krakowie, 11: 1-51.

Rasmussen, S.O., Bigler, M., Blockley, S.P., Blunier, T., Buchardt, S.L., Clausen, H.B., Cvijanovic, I., Dahl-Jensen,
D., Johnsen, S.J., Fischer, H., Gkinid, V., Guillevic, M., Hoek, W.Z., Lowe, J.J., Pedro, J.B., Popp, T., Seierstad, I.K., Steffensen, J.P., Svensson, A.M., Vallelonga, P., Vinther, B.M., Walker, M.J.C., Wheatley, J.J., Winstrup, M., 2014. A stratigraphic framework for abrupt climatic changes during the last glacial period based on three synchronized Greenland ice-core records: refining and extending the INTIMATE event stratigraphy. Quaternary Science Reviews, 106: 14-28.

Różański, K., Araguas-Araguas, L., Gonfiantini, R., 1993. Isotopic patterns in modern global precipitation. American Geophysical Union Geophysical Monograph, 78: 1-36.

Römer, F., 1883. Die Knochenhöhlen von Ojców in Polen. Palaeontographica, 29: 1-41.

Skrzypek, G., Wiśniewski, A., Grierson, P.F., 2011. How cold was it for Neanderthals moving to Central Europe during warm phases of the last glaciation? Quaternary Science Reviews, 30: 481-487.

Urbanowski, M. eds., 2013. Multidisciplinary Research 2006-2010. Stone Age Research (manuscript). Archaeological Department, Institute of History and International Relates, Szczecin University.

Urbanowski, M., Socha, P., Dąbrowski, P., Nowaczewska, W., Sadakierska-Chudy, A., Dobosz, T., Stefaniak, K., Nadachowski, A., 2010. The first Neanderthal tooth found north of the Carpathian Mountains. Naturwissenschaften, 97: 411-415.

Urbanowski, M., Żarski, M., Nadachowski, A., 2012. Stajnia Cave, the LMP site from Polish Jura. In: International Conference European Middle Palaeolithic during MIS 8-MIS 3 cultures - environment - chronology. Wolbrom, Poland, September 25th-28th, 2012 (eds. K. Cyrek, Ł.A. Czyżewski and M.T. Krajcarz): 24-26. Guide-book and book of abstracts, Toruń.

Valde-Nowak, P., Alex, B., Ginter, B., Krajcarz, M.T., Madeyska, T., Miękina, B., Sobczyk, K., Stefański, D., Wojtal, P., Zając, M., Zarzecka-Szubińska, K., 2014. Middle Paleolithic sequences of the Ciemna Cave (Pradnik valley, Poland): the problem of synchronization. Quaternary International, 326-327: 125-145.

Wasylikowa, K., 1964. Vegetation and climate of the Late-Glacial in central Poland based on investigations made at Witów near Łęczyca (in Polish with English summary). Biuletyn Peryglacjalny, 13: 261-417.

Woronko, B., 2001. Znaczenie analizy obtoczenia i zmatowienia powierzchni ziaren kwarcowych frakcji piaszczystej w interpretacji genetycznej osadów czwartorzędowych (in Polish). In: Eolizacja osadów jako wskaźnik stratygrafii czwartorzędu (ed. E. Mycielska-Dowgiałło): 33-39. Uniwersytet Warszawski, Warszawa.

Zarzycki, K., Trzcińska-Tacik, H., Różański, W., Szeląg, Z., Wołek, J., Korzeniak, U., 2002. Ecological Indicator Values of Vascular Plants of Poland. Szafer Institute of Botany, Polish of Academy Science, Kraków.

Zawisza, J., 1874. Jaskinia Mamutowa w dolinie Wierzchowskiej (in Polish). Wierzchowska Jaskinia, ogólny pogląd na jaskinie dotychczas zwiedzane w tej okolicy. Wiadomości Archeologiczne, 2: $1-23$

Żarski, M., Rywocka-Kenig, K., Winter, H., Marcinkowski, B., Surała, M., Mirosław-Grabowska, J., 2012a. Stratygrafia osadów plejstoceńskich stanowiska archeologicznego w jaskini Stajnia k. Mirowa na Wyżynie Krakowsko-Częstochowskiej (in Polish). Państwowy Instytut Geologiczny - Państwowy Instytut Badawczy, Warszawa.

Żarski, M., Winter, H., Marcinkowski, B., Rywocka-Kenig, K., 2012b. Palaeoenvironment and climate oscillations record from the Stajnia. In: International Conference European Middle Palaeolithic during MIS 8-MIS 3 cultures - environment - chronology. Wolbrom, Poland, September 25th-28th, 2012 (eds. K. Cyrek, Ł.A. Czyżewski and M.T. Krajcarz): 24-26. Guide-book and book of abstracts, Toruń. 